NBER WORKING PAPER SERIES

\title{
DISTRIBUTION COSTS AND REAL EXCHANGE RATE DYNAMICS DURING EXCHANGE-RATE-BASED-STABILIZATIONS
}

\author{
Ariel T. Burstein \\ João C. Neves \\ Sergio Rebelo \\ Working Paper 7862 \\ http://www.nber.org/papers/w7862 \\ NATIONAL BUREAU OF ECONOMIC RESEARCH \\ 1050 Massachusetts Avenue \\ Cambridge, MA 02138 \\ August 2000
}

\begin{abstract}
We are thankful to Vanessa Broda for providing us with price data for Argentina, to Federico Dorin for information on the construction of Argentine data, and to Martin Eichenbaum, Charles Engel, and Henry Siu for their comments. The views expressed herein are those of the authors and not necessarily those of the National Bureau of Economic Research.

(C) 2000 by Ariel T. Burstein, João C. Neves, and Sergio Rebelo. All rights reserved. Short sections of text, not to exceed two paragraphs, may be quoted without explicit permission provided that full credit, including (C) notice, is given to the source.
\end{abstract}


Distribution Costs and Real Exchange Rate Dynamics During

Exchange-Rate-Based-Stabilizations

Ariel T. Burstein, João C. Neves, and Sergio Rebelo

NBER Working Paper No. 7862

August 2000

JEL No. F41

\begin{abstract}
This paper studies the role played by the distribution sector in shaping the behavior of the real exchange rate during exchange-rate-based-stabilizations. We use data for the U.S. and Argentina to document the importance of distribution margins in retail prices and disaggregated price data to study price dynamics in the aftermath of Argentina's 1991 Convertibility plan. Distribution services require local labor and land so they drive a natural wedge between retail prices in different countries. We study in detail the impact of introducing a distribution sector in an otherwise standard model of exchange-ratebased-stabilizations. We show that this simple extension improves dramatically the ability of the model to rationalize observed real exchange rate dynamics.
\end{abstract}

Ariel T. Burstein

Department of Economics

Arthur Andersen Hall, Room 314

Northwestern University

2003 Sheridan Road

Evanston, IL 60208

Sergio Rebelo

Kellogg Graduate School of Management

Northwestern University

Evanston, IL 60208

and NBER

s-rebelo@northwestern.edu
João C. Neves

Universidade Católica Portuguesa

Palma de Cima

P-1600 Lisboa

Portugal 


\section{Introduction}

There is a large literature that studies the macroeconomic impact of exchangerate-based stabilizations. This literature has made substantial progress in explaining the behavior of consumption, investment and the current account during stabilizations (see Calvo and Végh (1999) for a recent survey). In contrast, the magnitude of the real exchange rate $(R E R)$ movements during these episodes remains difficult to understand.

Calvo and Végh (1999) find that the average $R E R$ appreciation between the year prior to the stabilization and the second year of the stabilization period in seven stabilization episodes in Argentina, Chile, Uruguay, and Israel was 20\%. ${ }^{1}$ In Argentina, the country we will use as benchmark in this paper, the real exchange rate appreciated by roughly $25 \%$ between April 1991, the date in which the Convertibility plan was enacted, and April 1993.

These large $R E R$ appreciations are at odds with the predictions of standard models. In a quantitative study of the effects of exchange-rate-based stabilizations Rebelo and Végh (1995) find an upper bound of roughly $8 \%$ for the increase in the relative price of non-tradables. This translates approximately into a $4 \%$ appreciation of the real exchange rate.

The standard model used to study exchange-rate-based stabilization features two goods, a tradable and a non-tradable. Purchasing power parity (PPP) is assumed to hold only for the tradable good. ${ }^{2}$ In this setting the $R E R$ fails to move

\footnotetext{
${ }^{1}$ Calvo and Vegh (1999) studied the period 1978-1993. The episodes included in their sample are: the 1978 'tablitas' in Argentina, Chile and Uruguay, the Argentine 1985 Austral plan, the 1990 Uruguay plan, and the 1991 Argentine Convertibility Act.

${ }^{2}$ For examples of models of exchange rate based stabilizations that rely on this assumption see Calvo and Végh (1993), Roldos (1995), Uribe (1997), and Mendoza and Uribe (1999). For an analysis of this class of models in a business cycle context see Stockman and Tesar (1995). Betts and Kehoe (1999) explore a more elaborate version of the tradables/non-tradables set up in which different goods vary in their degree of tradability.
} 
significantly when there is substitutability between tradables and non-tradables in utility or in production.

In Section 2 we use disaggregated price data for Argentina for the period 1991-1998 to study the price movements that underlie the large real exchange rate appreciation associated with the Convertibility plan enacted in April 1991. Using the comparable components of the CPI for the US and Argentina we find that most of the real exchange rate appreciation was due to increases in the prices of tradable goods. This suggests that understanding movements in the $R E R$ requires a model in which PPP does not hold for tradable goods.

To study whether the failure of PPP for tradable goods can be accounted for by the cost of local distribution services (transport, wholesale and retail services, marketing, etc.), we examine data on distribution margins for Argentina and the US. This data suggests that distribution costs represent at least half of the retail price of consumer goods. For some tradable agricultural products distribution accounts for roughly $80 \%$ of the final retail price of the product. Thus it is not surprising that, even though these goods are traded across countries, their prices are nor equalized.

Motivated by this empirical evidence we propose a model that embodies the notion, discussed in Sanyal and Jones (1982) and Erceg and Levin (1996), that there are no freely traded goods. ${ }^{3}$ We assume that all goods embody an important componerit of distribution services. Since these services are intensive in local labor and land and hence non-tradable, they create a natural wedge between the prices of tradable goods in different countries. Our analysis is complementary to that of Erceg and Levin (1996) who study the effects of technology shocks in models

\footnotetext{
${ }^{3}$ Dumas (1992), Sercu, Uppal, and Van Hulle (1995), and Benninga and Protopapadakis (1998) discuss models with international trade costs. These models are significantly different from ours because they assume that goods produced domestically can be distributed at no cost. For this reason they feature a no-trade zone-there are circumstances in which it is not worthwhile to pay the costs associated with international trade:
} 
that incorporate a distribution sector and investment in structures.

In Section 3 we review a standard small open economy model in which the $R E R$ is driven solely by the relative price of non-tradables. In Section 4 we introduce a distribution sector into the basic model. Section 5 discusses model calibration. In Section 6 we evaluate the quantitative implications of both models by studying a permanent stabilization. We show that the model with distribution produces much more realistic movements in the $R E R$ relative to the standard model. We then extend the distribution model by incorporating investment irreversibilities and capital immobility as well as a construction sector. In Section 7 we study the implications of the basic model, with and without a distribution sector for the case of a temporary stabilization. A final section summarizes the main results and discusses directions for future research.

\section{Empirical Motivation}

Table 1 describes the evolution of disaggregated price indexes for the various components of the Argentine consumer price index between March 1991 and March 1998. Table 2 reports the ratio of price indexes in Argentina and in the US for comparable components of the CPI. The interpretation of this data is not straightforward. The 1991 Convertibility Plan was not a pristine natural experiment that allows us to isolate the impact of the exchange-rate-based stabilization. Among the other shocks that impacted the Argentine economy was the Mercosur free trade agreement. This agreement began its implementation in June 1992, leading to a gradual lifting of tariffs on imports from Brazil, Uruguay and Paraguay. ${ }^{4}$ Tariffs on imports from non-Mercosur countries were also introduced in 1993 and 1995. In addition, various forms of price controls were eliminated after 1991.

\footnotetext{
${ }^{4}$ We suspect that the Mercosur tariff and quota reductions are the reason for the small price increases in a few tradable goods categories in Table 1, such as footwear.
} 
Table 2 shows that, relative to the US, the prices of some non-tradable goods and services increased significantly between 1991 and 1993, for example the price of educational services increased by $35 \%$. This table also suggest that the increases in the prices of certain non-tradable goods may have been moderated by price controls (examples are public transportation and medical care commodities). But the most surprising feature of the data summarized in these tables is that relative PPP does not hold for tradable goods. Relative to the US the price of alcoholic beverages and fats and oils increased by more than $30 \%$. The price of cereals, meats, non-alcoholic beverages and dairy all increased by more than $40 \%$.

We can use the data in Table 2 to compute the Argentine peso/US dollar $R E R$ based on the CPI. The categories in this table represent $68 \%$ and $74 \%$ of the goods included in the CPI of Argentina and the US, respectively. We renormalized the weights of the different goods in the US and Argentina so that they sum to $100 \%$ and constructed price indexes for tradables and non-tradables for both countries. ${ }^{5}$ We defined the real exchange rate in terms of the geometric consumer price indexes in the two countries:

$$
R E R=\left[S\left(P_{U S}^{T}\right)^{\gamma_{U S}}\left(P_{U S}^{N T}\right)^{1-\gamma_{U S}}\right] /\left[\left(P_{A r}^{T}\right)^{\gamma_{A r}}\left(P_{A r}^{N T}\right):{ }^{1-\gamma_{A r}}\right] .
$$

where $P_{i}^{T}$ and $P_{i}^{N T}$ are the prices of tradables and non-tradables in country $i$, respectively, and $S$ is the peso/dollar exchange rate. The variable $\gamma_{i}$ denotes the weight of tradable goods in the CPI of country $i$. The first panel of Figure 1 shows the evolution of the logarithm of the $R E R$ from April 1991 to March 1998 (the $R E R$ was normalized to one in April 1991). The $R E R$ appreciated by $25.3 \%$ in

\footnotetext{
${ }^{5}$ Our list of tradable goods is: Cereals, Meats, Dairy, Sugar and sweets, Fats and oils, Nonalcoholic beverages, Alcoholic beverages, Fuel and other utilities, Furniture and bedding, Housekeeping supplies, Footwear, New vehicles, Medical care commodities, Tobacco, Toilet Goods and personal care appliances, and School books and supplies. We classified as non-tradables the following goods: Food away from home, Rents (residential), Maintenance and repair of private tranportation, Public transportation, Medical care services, Personal care services, and College tuition.
} 
the first two years of the convertibility plan (from April 1991 to April 1993) and became roughly stable in subsequent periods.

We can to decompose the change in the US-Argentina RER along the lines suggested by Engel (1999). Since the nominal exchange rate has been constant during the period that we consider, we can express the change in the $R E R$ as:

$\Delta \log (R E R)=\Delta \log \left(P_{U S}^{T} / P_{A r}^{T}\right)+\left(1-\gamma_{U S}\right) \Delta \log \left(P_{U S}^{N T} / P_{U S}^{T}\right)-\left(1-\gamma_{A r}\right) \Delta \log \left(P_{A r}^{N T} / P_{A r}^{T}\right)$

Between April 1991 and April $1993 \Delta \log (R E R)=-25.3 \%$. Most of this change was accounted by movements in the price of tradable goods: $\Delta \log \left(P_{U S}^{T} / P_{A r}^{T}\right)=$ $-24.1 \%$ with only $-1.2 \%$ accounted for by movements in the relative price of nontradables.

There is other empirical evidence that suggest that the prices of tradable goods are inconsistent with the relative PPP hypothesis. Dornbusch (1989) summarizes data from the World Bank national income comparison project to show that the price of an identical consumption basket, constructed with detailed price data, is higher in high income countries than in low income economies. He suggests that distribution services may account for this failure of PPP. Giovannini (1988) rejects the absolute PPP hypothesis by comparing prices in the US and Japan for individual intermediate inputs used in manufacturing, such as nuts and bolts. Isard (1977) rejects the relative PPP hypothesis using highly disaggregated traded goods price indexes for the US, Canada, Germany, and Japan. Finally, Engel (1999) finds that the movements in the US real exchange rate cannot be accounted for by movements in the relative price of non-tradables. This accords with our findings for Argentina where most of the movement in the RER is accounted for changes in the prices of tradable goods.

Why does PPP fail for traded goods? Transportation costs seem too small to 
explain the observed large deviations from PPP. ${ }^{6}$ However, distribution costs as a whole (including wholesale and retail services, marketing, etc.) can be much more significant than the costs of transporting goods across countries. ${ }^{7}$ Feenstra (1998) discusses the production and distribution costs for Mattel's Barbie doll, which is a colorful, but suggestive example of the importance of distribution services in modern economies. The doll is produced in Asia at a cost of one dollar per unit ( 35 cents for labor and 65 cents for materials). It costs an additional dollar of distribution services to get the doll to the Hong Kong harbor, and then to the US. Mattel makes one dollar of profit from each doll. The sale price is $\$ 10$ dollars of which $\$ 7$ pay for transportation, marketing, and retail services in the US. Production costs are a mere $10 \%$ of the retail price of the product.

This example may be non-representative but there are many other instances in which the cost of distribution is significantly larger than the production cost. The US Department of Agriculture collects data on production and distribution costs for agricultural products. Table 3 shows the fraction of the retail price of food that is accounted for by the farm price of the produce. 'In all of the product categories distribution costs are more important than production costs. The weight of distribution costs in the final price range from $54 \%$ (eggs) to $82 \%$ (fresh fruits). ${ }^{8}$

The importance of distribution costs is not restricted to agricultural goods. Euromoney (1997, Table 3:48) estimates that in 1996 the average gross margin

\footnotetext{
${ }^{6}$ Rauch (1996) computes transporation costs (insurance and freight as percentage of customs value) for U.S. imports from Japan or similarly distant countries for 1970, 1980 and 1990 . He obtains estimates that range from $6 \%$ to $16 \%$. Hummels (1999) estimates the average tradeweighted freight cost in 1994 to be $3.8 \%$ for the U.S. and $7.5 \%$ for Argentina.

${ }^{7}$ See Rogoff (1996) and Froot and Rogoff (1995) for a comprehensive discussion of reasons for the failure of the PPP hypothesis, including pricing to market behavior.

${ }^{8}$ This weight does not seem closely related to the perishable character of the different goods. For example, fats and oils, which are arguably less perishable than eggs, have a distribution weight of $79 \%$.
} 
as a percentage of retail sales in the US across all goods except automobiles was $36.2 \%$.

The 1992 Input-Output table for the US economy is another source of valuable information on the importance of distribution costs. This information is summarized in Tables 4 and 5 . Note that in some sectors the distribution costs could not be isolated from the production costs, since some goods are sold directly by the producer to the retailer or consumer (see Betancourt (1992)). For this reason the estimates in these table are likely to represent a lower bound on the importance of distribution.

\begin{tabular}{|l|c|}
\hline \multicolumn{2}{|c|}{ Table 3. } \\
\hline \multicolumn{2}{|c|}{ Farm Value Share of } \\
\hline \multicolumn{2}{|c|}{ Retail Cost (\%), 1997} \\
\hline Meat Products & 36 \\
\hline Poultry & 41 \\
\hline Eggs & 46 \\
\hline Dairy Products & 32 \\
\hline Fats and Oils & 21 \\
\hline Fresh Fruits & 18 \\
\hline Fresh Vegetables & 21 \\
\hline $\begin{array}{l}\text { Source: Economic Research Service, } \\
\text { US Dept. of Agriculture. }\end{array}$ \\
\hline
\end{tabular}

\footnotetext{
${ }^{9}$ http://www.econ.ag.gov/briefing/foodmark/cost/data/index/basket2.htm
} 


\begin{tabular}{|l|l|l|l|l|}
\hline \multicolumn{5}{|c|}{ Table 4 } \\
\hline \multicolumn{5}{|c|}{ Share of distribution costs in the purchasers price values } \\
\hline & $\begin{array}{c}\text { Agriculture, forsonal } \\
\text { Consumption } \\
\text { Expenditures }\end{array}$ & $\begin{array}{c}\text { Gross Privates and mining (\%) } \\
\text { Fixed } \\
\text { Investment }\end{array}$ & $\begin{array}{c}\text { Exports of } \\
\text { Goods and } \\
\text { Services }\end{array}$ & $\begin{array}{c}\text { Fed. Government } \\
\text { Consumption and } \\
\text { Gross Investment }\end{array}$ \\
\hline Weighted Average & 46.73 & 22.34 & 21.62 & 40.80 \\
\hline Standard Deviation & 25.06 & 20.91 & 14.63 & 23.86 \\
\hline Max & 64.22 & 29.58 & 42.16 & 72.60 \\
\hline Min & 0.00 & 0.00 & 0.00 & -0.12 \\
\hline \# Relevant Sectors & 6 & 2 & 8 & 8 \\
\hline Source: 1992 US Input-Output Matrix & \multicolumn{3}{|c|}{} \\
\hline
\end{tabular}

Tables 4 and 5 suggest that consumption goods embody an important element of distribution services: these services represent $47 \%$ of the final price in the agricultural sector and $42 \%$ in manufacturing. In contrast, distribution services play a smaller role in investment, exports, imports and government spending.

\begin{tabular}{|l|l|l|l|l|}
\hline \multicolumn{5}{|c|}{ Table 5 } \\
\hline \multicolumn{5}{|c|}{ Share of distribution costs in the purchasers price values } \\
\hline & $\begin{array}{c}\text { Personal } \\
\text { Consumption } \\
\text { Expenditures }\end{array}$ & $\begin{array}{c}\text { Gross Private } \\
\text { Fixed } \\
\text { Investment }\end{array}$ & $\begin{array}{c}\text { Exports of } \\
\text { Goods and } \\
\text { Services }\end{array}$ & $\begin{array}{c}\text { Fed. Government } \\
\text { Consumption and } \\
\text { Gross Investment }\end{array}$ \\
\hline Weighted Average & 41.75 & 16.01 & 11.83 & 8.61 \\
\hline Standard Deviation & 10.83 & 9.66 & 5.12 & 6.63 \\
\hline Max & 59.21 & 37.43 & 24.93 & 27.01 \\
\hline Min & 11.09 & 0.00 & 1.73 & 0.57 \\
\hline \# Relevant Sectors & 48 & 32 & 52 & 52 \\
\hline Source: 1992 US Input-Output Matrix & \\
\hline
\end{tabular}

A complementary source of information on US distribution costs are the Census of Wholesale and Retail Trade published by the Department of Commerce. Table 6 summarizes the information contained in these surveys regarding margins, value added and labor costs. The distribution margin, computed as value 
added/sales is $30 \%$ in the retail sector and $20 \%$ in the wholesale sector. ${ }^{10}$ This means that the distribution component of a good that is sold by the producer to the wholesaler and then from the wholesaler to the retailer represents $44 \%$ of the retail price. However, not all goods go through both distribution channels.

Data on distribution costs in Argentina is scarce. However, the information that exists, summarized in Table 7, suggests that distribution margins are high, on the order of $61 \%$ of the retail price. ${ }^{11}$ These high margins probably reflect inefficiencies in the Argentine distribution system. Bailey (1993) and Itoh (2000) attribute the high distribution margins observed in Japan to a system of small retail stores and long tunnels of small wholesalers. Similar problems seem to plague the Argentine distribution system, which is comprised by numerous small retailers. ${ }^{12}$

\footnotetext{
${ }^{10}$ Value added is computed as the gross margin less the cost of supplies, materials, fuel and other energy, and the cost of contract work on materials of the wholesaler. The gross margin is computed as sales less cost of goods sold.

${ }^{11}$ We cannot extract information about distribution costs from the 1997 input-output matrix for Argentina. This matrix is computed using "basic prices" which exclude distribution margins and transportation costs as well as indirect taxes and subsidies. Data on distribution margins for Argentina is currently being produced for 1997. In the preliminary version of this data, the margins for most sectors are in the $20 \%-40 \%$ range. This information is not comparable with that of Table 6 because it mixes consumer goods with intermediate inputs and investment goods. The fact that intermediate inputs and investment goods have lower distribution margins probably accounts for the lower margin estimates in this preliminary data.

${ }^{12}$ The Census of Retail and Wholesale estimates that there were 506,659 establishments in the sector in 1993; roughly one establishment for every 70 inhabitants. Large supermarkets account only for $5.4 \%$ of the employment in the retail sector in 1999 according to the Coordinadora de Actividades Mercantiles Empresariais.
} 


\begin{tabular}{|l|c|c|l|l|}
\hline \multicolumn{5}{|c|}{ Table 7 } \\
\hline \multicolumn{5}{|c|}{$\begin{array}{c}\text { Production and Value Added } \\
\text { Census of Wholesale and Retail Commerce } \\
\text { Argentina, 1993 } \\
\text { 506,659 Establishments } \\
\text { (Billions of Pesos) }\end{array}$} \\
\hline \multicolumn{7}{|c|}{$\begin{array}{c}\text { Wholesale } \\
\text { and Retail }\end{array}$} & Wholesale & Retail \\
\hline$(1)$ & Intermediate Inputs & 9.21 & 5.40 & 3.80 \\
\hline$(2)$ & Labor Income & 4.93 & 2.92 & 2.01 \\
\hline$(3)$ & $\begin{array}{c}\text { Taxes, Depreciation } \\
\text { and Interest }\end{array}$ & 3.28 & 1.81 & 1.47 \\
\hline$(4)$ & $\begin{array}{c}\text { Other Components } \\
\text { of Value Added }\end{array}$ & 9.84 & 4.85 & 4.99 \\
\hline$(5)$ & Total Value Added & 18.05 & 9.58 & 8.47 \\
\hline$(6)$ & Value of Production & 27.26 & 14.98 & 12.27 \\
\hline \hline$(7)$ & $\begin{array}{c}\text { Distribution Margin } \\
\text { [(5)-(3)]/[(6)-(3)] }\end{array}$ & $61.60 \%$ & $58.98 \%$ & $64.79 \%$ \\
\hline \hline Source: INDEC & & & \\
\hline
\end{tabular}

To shed more light on the importance of distribution costs in Argentina, we computed the RER using the wholesale price index (WPI) for Argentina and the US producer price index. This measure of the $R E R$, is displayed on the second panel of Figure 1. While the CPI-based RER appreciated by $25.3 \%$ in the first two years of the stabilization plan, the WPI-based $R E R$ appreciated only by $2.7 \%$. This reflects the absence of non-tradables from the WPI, as well as its lower distribution cost component. 


\begin{tabular}{|l|l|l|l|l|}
\hline \multicolumn{5}{|c|}{ Table 8 } \\
\hline \multicolumn{5}{|c|}{ Uectoral Employment and Value Added } \\
\hline \multicolumn{5}{|c|}{ US and Argentina, 1997 } \\
\hline Sector & $\begin{array}{l}\text { Employment } \\
\text { (\% of total) }\end{array}$ & $\begin{array}{c}\text { Value Added } \\
\text { (\% of total) }\end{array}$ & $\begin{array}{c}\text { Employment } \\
\text { (\% of total) }\end{array}$ & $\begin{array}{c}\text { Value Added } \\
\text { (\% of total) }\end{array}$ \\
\hline Retail & 17.9 & 7.3 & n.a & n.a \\
\hline Wholesale & 5.4 & 9.8 & n.a & n.a \\
\hline Retail and Wholesale & 23.3 & 17.1 & 21.4 & 16.1 \\
\hline Manufacturing & 15.2 & 18.8 & 15.1 & 18.2 \\
\hline $\begin{array}{c}\text { Services (excluding } \\
\text { Retail and Wholesale) }\end{array}$ & 40.4 & 45.8 & 47.7 & 54.0 \\
\hline Government & 15.9 & 12.2 & n.a & n.a \\
\hline${ }^{*}$ Excluding agriculture. & \multicolumn{3}{l|}{} \\
\hline Source: US Bureau of Economic Analysis and INDEC. \\
\hline
\end{tabular}

Table 8 describes the structure of employment and value added in the US and in Argentina in 1997. This table, which shows that the distribution sector is large, both in terms of employment and value added, provides further evidence that distribution costs are economically significant.

The evidence described above suggests an obvious, simple way of improving both the realism and the performance of existing models: the introduction of a distribution sector whose services are necessary so that tradable goods can be consumed. We will show that the way in which distribution services are introduced is important, both for the fraction of $R E R$ variation that is accounted for by changes in the relative price of non-tradables and for the behavior of the tradable-non-tradable consumption mix. At the same time, this evidence can be interpreted as fitting squarely into the standard tradables-non-tradables framework. However, we will see that the implications of our model with distribution cannot be replicated by increasing the share of non-tradable consumption in the standard model. 


\section{A Basic Model}

We start by reviewing a simple version of the standard tradables-non-tradables model, similar to that used in Rebelo and Végh (1995). This will establish a benchmark against which we can compare the model with distribution that we study later.

Consider a small open economy with no barriers to the flow of tradable goods, so that purchasing power parity holds for this good:

$$
P_{t}^{T}=S_{t} P_{t}^{T *}
$$

Here $P_{t}^{T}$ and $P_{t}^{T *}$ denote the domestic and foreign price of the tradable good, respectively. The exchange rate, defined as units of domestic currency per unit of foreign currency, is denoted by $S_{t}$.

\section{The Household's Problem}

The representative household seeks to maximize lifetime utility $(U)$ defined over sequences of consumption of tradable $\left(C_{t}^{T}\right)$ and non-tradable goods $\left(C_{t}^{N T}\right)$ :

$$
\begin{aligned}
U & =\sum_{t=0}^{\infty} \beta^{t} \frac{\left[\left(C_{t}^{T}\right)^{\gamma}\left(C_{t}^{N T}\right)^{1-\gamma}\right]^{1-\sigma}-1}{1-\sigma} \\
0 & <\gamma<1 ; \sigma>0,0<\beta<1,
\end{aligned}
$$

where $\beta$ is the discount factor and $\sigma$ is the inverse of the intertemporal elasticity of substitution. Each agent supplies inelastically $N$ units of time per period which are allocated between the tradables $\left(N_{t}^{T}\right)$ and non-tradables $\left(N_{t}^{N T}\right)$ sectors:

$$
N_{t}^{T}+N_{t}^{N T}=N
$$

Households also supply capital to the tradable $\left(K_{t}^{T}\right)$ and non-tradable $\left(K_{t}^{N T}\right)$ sectors. For most of our analysis we assume that capital $\left(K_{t-1}\right)$ can be freely reallocated across these sectors: 


$$
K_{t-1}=K_{t}^{T}+K_{t}^{N T}
$$

The law of motion for the aggregate capital stock is:

$$
K_{t}=I_{t}+(1-\delta) K_{t-1}
$$

We abstract from adjustment costs in capital accumulation, which are a standard element in small open economy models, for two reasons. First, to study the magnitude of $R E R$ movements that can be generated by the model, it is sufficient to measure the impact effect (which occurs in the first period, when the stock of capital is fixed) and the steady state effect (which immediately occurs in the second period). Adjustment costs smooth out the steady state effect over time. ${ }^{13}$ Second, we later introduce additional features into the model-investment irreversibility, immobility of capital across sectors and a construction sector-that produce a smooth adjustment towards the steady state. This allows us to evaluate how much these features in isolation contribute to generating realistic investment dynamics.

In addition to accumulating physical capital, households can borrow and lend in the international capital market at rate $r$. Their net foreign asset holdings in the beginning of period $t$ are denoted by $b_{t-1}$. To abstract from the presence of trends in the current account, we assume that $\beta=(1+r)^{-1}$. The household's intertemporal budget constraint is:

$$
W_{t} N+Q_{t} K_{t-1}+P_{t}^{T}\left(\pi_{t}^{T}+\pi_{t}^{N T}+\Omega_{t}\right)+S_{t} b_{t-1}(1+r)
$$

\footnotetext{
${ }^{13}$ Adjustment costs also reduce somewhat the movement in the RER that the model generates. The fact that investment is costly to adjust reduces the wealth effect and hence the expansion in the consumption of non-tradables that underlies the RER movements. Since this effect is symmetric in the model with and without distribution costs, the absence of adjustment costs does not bias our comparisons.
} 


$$
=P_{t}^{T}\left(C_{t}^{T}+I_{t}+Z_{t}\right)+P_{t}^{N T} C_{t}^{N T}+S_{t} b_{t}+M_{t}-M_{t-1} .
$$

Here $P_{t}^{N T}$ is the nominal price of non-tradable good. The variable $W_{t}$ represents the nominal wage rate, while $Q_{t}$ is the nominal rental price of capital. The variable $\Omega_{t}$ represents real lump sum transfers from the government measured in units of the tradable good. Domestic money holdings in the beginning of period $t$ are denoted by $M_{t-1}$. The variables $\pi^{T}$ and $\pi^{N T}$ denote profits (measured in units of tradables) in the tradable and non-tradable sectors, respectively. Finally, $Z_{t}$ represents transactions expenditures which we discuss further below. The noPonzi game condition for the representative household is: $\lim _{t \rightarrow \infty} b_{t} /(1+r)^{t}=0$.

Money is used for transactions according to a specification in which holdings of real money balances expressed in terms of traded goods allow the agent to economize on the amount of resources devoted to transactions. We denote these resources by $Z_{t}$ and assume that they are denominated in terms of tradable goods:

$$
Z_{t}=A^{S}\left(C_{t}+I_{t}\right) v\left[\frac{M_{t} / P_{t}^{T}}{C_{t}+I_{t}}\right]
$$

where $M_{t}$ is the amount of cash held by households, and $A^{S}$. is a level parameter. Total consumption measured in units of the tradable good is given by

$$
C_{t}=C_{t}^{T}+p_{t} C_{t}^{N T}
$$

where $p_{t}$ is the relative price of non-tradables:

$$
p_{t}=P_{t}^{N T} / P_{t}^{T} .
$$

We assume that the function $v($.$) has the following quadratic form:$

$$
v(X)=X^{2}-X+1 / 4,
$$

where $X_{t}=M_{t} /\left[P_{t}^{T}\left(C_{t}+I_{t}\right)\right]$ is the inverse of the velocity of circulation with respect to total expenditure. This quadratic form, borrowed from Végh (1989), 
ensures that transactions costs are zero when the nominal interest rate is zero. When $R=0$ it is optimal to set $X$ to $1 / 2$ and $v(1 / 2)=0$. Note that for $X<1 / 2$, the function $v(X)$ is decreasing in $X$. This means that increasing the amount of money held by the households while keeping total consumption, $C_{t}$ constant, reduces the transactions costs $Z$.

The household's problem then consists of maximizing lifetime utility, defined in (3.2), subject to the constraints (3.3)-(3.10).

\section{The Firms' Problem}

Production of tradables $\left(Y_{t}^{T}\right)$ and non-tradables $\left(Y_{t}^{N T}\right)$ are described by the following Cobb-Douglas production functions, where $A^{T}$ and $A^{N T}$ are time-invariant level parameters: ${ }^{14}$

$$
\begin{gathered}
Y_{t}^{T}=A^{T}\left(K_{t}^{T}\right)^{1-\alpha}\left(N_{t}^{T}\right)^{\alpha} \quad 0<\alpha<1 \\
Y_{t}^{N T}=\left\{v\left[A^{N T}\left(K_{t}^{N T}\right)^{1-\eta}\left(N_{t}^{N T}\right)^{\eta}\right]^{(1+\rho) / \rho}+(1-v) T^{\langle 1+\rho) / \rho}\right\}^{\rho /(1+\rho)}
\end{gathered}
$$

The variable $T$ denotes the fixed stock of land in the economy. ${ }^{15}$ The tradable good $Y_{t}^{T}$ can be used for investment or consumption, while the non-tradable good can only be consumed.

Firms hire labor and capital from households to maximize their profits, measured in units of the tradable good:

\footnotetext{
${ }^{14}$ To improve the model's implications for the behavior of the real exchange rate, Rebelo and Végh (1995) assume that the production of non-tradables does not require capital.

${ }^{15}$ Our model abstracts from housing; all land is used in the non-tradables sector for production and distribution. However, as Erceg and Levin (1996) stress, housing costs can have a very significant direct impact on the CPI. In the case of Argentina, the cost of residential housing rose by $122 \%$ between March 1991 and March 1993. This large increase had, however, a relatively small impact on the CPI because rents have a surprisingly low weight in the index $(2.3 \%$, see Table 1). This is probably due to the fact that housing services consumed by home owners are not imputed as rents.
} 


$$
\begin{aligned}
\pi^{T} & =Y_{t}^{T}-\left(Q_{t} / P_{t}^{T}\right) K_{t}^{T}-\left(W_{t} / P_{t}^{T}\right) N_{t}^{T} \\
\pi^{N T} & =p_{t} Y_{t}^{N T}-\left(Q_{t} / P_{t}^{T}\right) K_{t}^{N T}-\left(W_{t} / P_{t}^{T}\right) N_{t}^{N T}
\end{aligned}
$$

\section{The Government}

We consider two cases. In the first, the government rebates the seignorage revenue to the households through lump sum transfers: In the second case, seignorage revenue is used to finance government spending that does not affect private utility or production. Real government net foreign asset holdings $\left(f_{t}\right)$ evolve according to:

$$
S_{t} f_{t}=S_{t} f_{t-1}(1+r)+M_{t}^{S}-M_{t-1}^{S}-P_{t}^{T} \Omega_{t}
$$

The no-Ponzi game condition for the government is: $\lim _{t \rightarrow \infty} f_{t} /(1+r)^{t}=0$. Together these two equations define the government's present value budget constraint.

\section{Monetary Policy}

Since we are interested in fixed exchange rate regimes we model the rate of devaluation $\varepsilon_{t}$ as the exogenous policy parameter that the government controls. The level of $M_{t}$ will be endogenously determined by money demand. We will study the exchange-rate-based stabilization experiment that is conventional in the literature. We start the economy in a steady state with $\varepsilon>0$ and study the impact of an unanticipated reduction in $\varepsilon$ to zero.

\section{The Competitive Equilibrium}

A perfect foresight competitive equilibrium for this economy is a set of paths for quantities $\left\{C_{t}^{T}, C_{t}^{N T}, N_{t}^{T}, N_{t}^{N T}, K_{t}^{T}, K_{t}^{N T}, K_{t}, I_{t}, Z_{t}, b_{t}, M_{t}, M_{t}^{S}, \Omega_{t}, f_{t}, \pi_{t}^{T}, \pi_{t}^{N T}\right\}$ and prices $\left\{S_{t}, W_{t}, Q_{t}, P_{t}^{T}, P_{t}^{N T}\right\}$ such that (i) $C_{t}^{T}, C_{t}^{N T}, I_{t}, K_{t}, Z_{t}, b_{t}, M_{t}$ solve the household's problem given the path for prices and profits; (ii) the government's intertemporal budget constraint holds; (iii) the labor market clears, $N_{t}^{T}+N_{t}^{N T}=N$; 
(iv) the capital market clears, $K_{t-1}=K_{t}^{T}+K_{t}^{N T}$; (v) the money market clears, $M_{t}^{S}=M_{t}$; (vi) the exchange rate market clears, $P_{t}^{T}=S_{t} P_{t}^{T *}$; (vii) the market for the non-tradable good clears, $C_{t}^{N T}=Y_{t}^{N T}$; and (viii) the tradable good market clears, which requires:

$$
\begin{aligned}
Y_{t}^{T}= & C_{t}^{T}+I_{t}^{T}+Z_{t}+T B_{t}, \\
a_{t}= & (1+r) a_{t-1}+T B_{t}, \\
& \lim _{t \rightarrow \infty} a_{t} /(1+r)^{t}=0,
\end{aligned}
$$

where $a_{t}=b_{t}+f_{t}$ represents the consolidated net asset holdings of the government and the private sector, while $T B_{t}$ is the economy's trade balance. ${ }^{16}$

\section{The Real Exchange Rate}

In order to compare the implications of the model with the data it is important to note that the $R E R$ does not coincide with the relative price of non-tradables. The geometric consumer price index for this economy is:

$$
P_{t}=\left(P_{t}^{T}\right)^{\gamma}\left(P_{t}^{N T}\right)^{1-\gamma}
$$

The real exchange rate in this economy is given by:

$$
R E R=\frac{S_{t}\left(P_{t}^{T *}\right)^{\gamma}\left(P_{t}^{N T *}\right)^{1-\gamma}}{\left(P_{t}^{T}\right)^{\gamma}\left(P_{t}^{N T}\right)^{1-\gamma}}
$$

where, to simplify, we assumed the CPI weights are the same in the two countries. ${ }^{17}$ This has no consequences since we will assume that the foreign relative

\footnotetext{
${ }^{16}$ The current account is given by $C A_{t}=r a_{t-1}+T B_{t}$. In the absence of shocks, this economy is always at a steady state where $T B=-r a$. Any level of $a$ is consistent with the steady state. Positive levels of net foreign asset holdings allow the economy to finance a trade deficit that makes it possible to enjoy higher levels of consumption of both goods.

${ }^{17}$ In practice, the consumer price index is computed according to an arithmetic average, instead of a geometric average. In our simulations the behavior of the real exchange rate is very similar for both arithmetic and geometric CPI's.
} 
price of non-tradables, $p_{t}^{*}=P_{t}^{T *} / P_{t}^{N T *}$, is constant over time. This assumption, together with (3.9), allows us to re-write the $R E R$ as:

$$
R E R=\frac{S_{t} P_{t}^{T *}\left(p^{*}\right)^{1-\gamma}}{P_{t}^{T}\left(p_{t}\right)^{1-\gamma}}=\frac{\left(p^{*}\right)^{1-\gamma}}{p_{t}^{1-\gamma}}
$$

It is standard in the literature to equate the $R E R$ with the relative price of nontradables. Since $\gamma<1$ the movements in the $R E R$ reported in the literature would be even smaller, if they were computed according to (3.17).

\section{Introducing Distribution Services}

We now introduce a distribution sector to our basic model by assuming that tradable goods need to be combined with distribution services before they are consumed. To avoid complicating the analysis we abstract from the presence of distribution services in the non-tradables sector. We also aggregate the production of non-tradables and distribution services into a single sector. Preferences are the same as before and the only modification to the technology is:

$$
\phi C_{t}^{T}+C_{t}^{N T}=\left\{v\left[A^{N T}\left(K_{t}^{N T}\right)^{1-\eta}\left(N_{t}^{N T}\right)^{\eta}\right]^{(1+\rho) / \rho}+(1-v) T^{(1+\rho) / \rho}\right\}^{\rho /(1+\rho)}
$$

where $\phi$ is the amount of distribution services required to sell one unit of consumption. This formulation of the distribution sector is identical to that used by Erceg and Levin (1996).

To compute the exchange rate for this economy it is useful to define the producers price of the traded good as $\bar{P}_{t}^{T}$ in the domestic economy and as $\bar{P}_{t}^{T *}$ in the foreign country. Note that households cannot purchase the tradable good at these prices, they pay retail prices which are given by:

$$
\begin{aligned}
P_{t}^{T} & =\bar{P}_{t}^{T}+\phi P_{t}^{N T}, \\
P_{t}^{T *} & =\tilde{P}_{t}^{T *}+\phi P_{t}^{N T *}
\end{aligned}
$$


where, for symmetry, we use the same value of $\phi$ in the two countries. Using (3.17) we can write the $R E R$ as:

$$
R E R=\frac{S_{t}\left(\bar{P}_{t}^{T *}+\phi P_{t}^{N T *}\right)^{\gamma}\left(P_{t}^{N T *}\right)^{1-\gamma}}{\left(\bar{P}_{t}^{T}+\phi P_{t}^{N T}\right)^{\gamma}\left(P_{t}^{N T}\right)^{1-\gamma}} .
$$

It is useful to define $p_{t}=P_{t}^{N T} / \ddot{P}_{t}^{T}$ and $p_{t}^{*}=P_{t}^{N T *} / \bar{P}_{t}^{T *}$. These are the relative price of non-tradables in terms of tradables exclusive of distribution services in each of the two countries. We can then re-write the $R E R$ as:

$$
R E R=\frac{S_{t} \bar{P}_{t}^{T *}\left(1+\phi p_{t}^{*}\right)^{\gamma}\left(p_{t}^{*}\right)^{1-\gamma}}{\bar{P}_{t}^{T}\left(1+\phi p_{t}\right)^{\gamma} p_{t}^{1-\gamma}} .
$$

Here we assume that PPP holds for producer prices of tradable goods: ${ }^{18}$

$$
S_{t} \bar{P}_{t}^{T *}=\bar{P}_{t}^{T} .
$$

Equation (4.1) together with the assumption that $p_{t}^{*}$ is constant over time, implies that the real exchange rate is given by:

$$
R E R=\frac{\left(1+\phi p^{*}\right)^{\gamma}\left(p^{*}\right)^{1-\gamma}}{\left(1+\phi p_{t}\right)^{\gamma} p_{t}^{1-\gamma}} .
$$

This formula shows that the introduction of distribution in the standard model can potentially magnify the movements in the $R E R$. A given movement in $p_{t}$ has a larger effect on the $R E R$ when $\phi>0$ than when $\phi=0$. However, since $p_{t}$ is determined in equilibrium, this formula alone cannot tell us whether the model with distribution produces larger $R E R$ movements. It is possible that in the model with distribution movements in $p$ will be small, leading to smaller movements in the $R E R$ than the basic model.

Note that not all forms of distribution costs necessarily magnify movements in the real exchange rate. Suppose, for example, that to distribute one tradable good

\footnotetext{
${ }^{18}$ There is some evidence that this weak form of PPP may hold in practice. One reason why PPP holds for gold contracts is that these do not include delivery of the gold. In other words, the price of gold quoted in exchanges is exclusive of delivery services.
} 
requires $\phi$ units of tradables. Under this 'iceberg cost' assumption often used in the trade literature, the retail price of tradable goods is given by $P_{t}^{T}=\bar{P}_{t}^{T}(1+\phi)$, and $P_{t}^{T *}=\bar{P}_{t}^{T *}(1+\phi)$. It is easy to see that using these equations in (3.17) we obtain the same formula for the $R E R$ as in the economy without distribution costs (equation (3.18))

\section{Calibrating the Models}

To conduct our experiments we calibrate the model to replicate the average values of some key ratios for the Argentine economy in the decade prior to the 1991 Convertibility Plan. Each time interval represents one quarter. All numerical results were computed using a shooting numerical routine. ${ }^{19}$

Our baseline parameters are summarized in Table 11. We used the same rate of inflation for the pre-stabilization period as Uribe (1997) in his study of the Convertibility Plan: $25 \%$ per month, which is equivalent to $95 \%$ per quarter. The value of $\sigma$ corresponds to the estimate of the elasticity of intertemporal substitution obtained by Reinhart and Végh (1995) for Argentina. We chose $\gamma$ so that $50 \%$ of consumption expenditures were devoted to non-tradable goods.

We chose $A^{T}$ and $A^{N T}$ to be identical and set their value so as to generate plausible capital-labor ratios in the two sectors. The stock of land, $T$, was chosen so that the relative price of non-tradables is equal to one in the initial no-stabilization steady state. Neither of these parameters influence the change in the $R E R$ that

\footnotetext{
${ }^{19}$ In the models where the transition to the steady state occurs in one period we solved the model using simple shooting. This technique no longer worked in the case of a temporary stabilization or in the models with a construction sector or irreversible investment. In these cases we solved the model using a two stage algorithm. In the first stage we searched for solutions such that the economy converged to a steady state in $T$ periods, where $T$ was a small number. We obtained these $T$ period solutions for a smooth sequence of $\varepsilon$ 's, starting with the value of $\varepsilon$ in the pre-stabilization steady state $(95 \%)$ until $\varepsilon=0$. In the second stage we started with the solution for $\varepsilon=0$ and increased $T$ until the constraint that the system must reach a steady state in $T$ periods was no longer binding.
} 
occurs in response to a stabilization; they simply control the level of different variables.

We chose the transactions technology parameter $A^{S}$ to match the $7 \%$ ratio of seignorage to GDP estimated by Kiguel (1989) for the period 1984-87. The level of net foreign assets, $a$, was chosen so as to generate a steady state trade balance to GDP ratio that coincides with the long run average for this variable in the period 1970-1990 (2.7\%).

In the model with distribution we set $\phi$ to 1 . This implies that half of the retail price is accounted for by distribution services. In the basic model, $\phi$ is set equal to zero.

Table 9, constructed with input-output data, depicts the labor share in value added for different US industries. Table 10 depicts the sectoral labor shares for Argentina that we use to calibrate the model. These shares are very sensitive to whether we treat "mixed income," (an income category similar to proprietors income in US data) as labor or capital compensation. The shares in Table 10 were computed by eliminating mixed income from total income.

\begin{tabular}{|l|c|c|c|}
\hline \multicolumn{4}{|c|}{ Table 9 } \\
\hline & $\begin{array}{c}\text { Lalue Added } \\
\text { Simple Average }\end{array}$ & $\begin{array}{c}\text { Value Added } \\
\text { Weighted Average }\end{array}$ & $\begin{array}{c}\text { Total } \\
\text { Inputs }\end{array}$ \\
\hline $\begin{array}{c}\text { Agriculture,Forestry, } \\
\text { Fisheries and Mining }\end{array}$ & 0.50 & 0.51 & 0.23 \\
\hline Construction & 0.78 & 0.78 & 0.36 \\
\hline Manufacturing & 0.66 & 0.66 & 0.27 \\
\hline All Services, of which: & 0.65 & 0.65 & 0.36 \\
\hline Distribution Services & 0.67 & 0.66 & 0.34 \\
\hline Other Services & 0.64 & 0.64 & 0.37 \\
\hline Sources: US 1992 Input-Output Table & & \\
\hline
\end{tabular}

\footnotetext{
${ }^{20}$ The definition of the different industries in terms of sectors of the Input output matrix is as follows. Agriculture, forestry, fisheries and mining comprises sectors 1-10, construction
} 


\begin{tabular}{|l|c|}
\hline \multicolumn{2}{|c|}{ Table 10 } \\
\hline \multicolumn{2}{|c|}{$\begin{array}{l}\text { Labor Share in Value Added } \\
\text { Argentina, Average 1993-1997 }\end{array}$} \\
\hline $\begin{array}{c}\text { Agriculture, Forestry, } \\
\text { Fisheries and Mining }\end{array}$ & 0.22 \\
\hline Manufacturing & 0.532 \\
\hline Services & 0.497 \\
\hline $\begin{array}{c}\text { Agriculture,Forestry, } \\
\text { Fisheries and Mining } \\
\text { and Manufacturing }\end{array}$ & 0.41 \\
\hline $\begin{array}{l}\text { Source: Informe Económico, n. 30,1999 } \\
\text { Ministério de Economia, Argentina }\end{array}$ \\
\hline
\end{tabular}

We set the labor share in the tradable sector $(\alpha)$ to $41 \%$, which is the average labor share in the non-service sector in Argentina. The parameters $\nu$ and $\eta$ were chosen so that in our baseline parameterization, the labor share in the nontradable sector coincides with our estimates for the share of labor in the Argentine service sector (50\%). Our parameter choices resulted in a share of land income in total income of $9 \%$ in the initial steady state of the baseline model. While this value strikes us as reasonable, it is difficult to compare with empirical evidence because land income is often included in profits.

Unfortunately, we could not find any empirical studies to guide our choice for $\rho$, the elasticity of substitution between labor and land. To overcome this problem we tried to choose a reasonable value for our baseline calibration $(-1 / 3)$ and then studied the behavior of the $R E R$ in the two models for different values of $\rho$ (see Table 14).

sectors 11-12, manufacturing sectors 13-64, all services 65-84, distribution services 65-66, 69 and 73D, and other services 67-68,70-73C,74-84. To explain our computations it is useful to define $w_{i}=$ Compensation of employees in sector $i$ and $V_{i}=$ Value Added - Indirect Business Tax and NonTax Liability in sector $i$. The labor share computed as a average is given by: $\left[\sum_{i=1}^{n}\left(w_{i} / V_{i}\right)\right] / n$. The weighted average was computed as $\left(\sum_{i=1}^{n} w_{i}\right) /\left(\sum_{i=1}^{n} V_{i}\right)$. The labor share in total inputs for sector $i$ was computed as $\sum_{j=1}^{n} a_{i j} w_{j} / V_{j}$, where $a_{i j}$ is the materials requirement of sector $i$ from sector $j$.

${ }^{21}$ Value added was evaluated using producers prices and excluding specific taxes. 


\begin{tabular}{|l|l|}
\hline \multicolumn{2}{|c|}{ Table 11 } \\
\hline \multicolumn{2}{|c|}{ Parameters, Basic Model } \\
\hline$\sigma=5$ & Inverse of the Elasticity of Intertemporal Substitution \\
\hline$\varepsilon=0.95$ & Quarterly depreciation rate in the pre-stabilization period \\
\hline$\alpha=0.41$ & Labor share, tradable sector \\
\hline$\rho=-1 / 3$ & $\begin{array}{l}\text { Elasticity of substitution between value added and } \\
\text { land, non-tradables production }\end{array}$ \\
\hline$\eta=0.71$ & Parameter, non-tradables production function \\
\hline$\nu=0.159$ & Parameter, non-tradables production function \\
\hline$\gamma=0.5$ & Share parameter, utility function \\
\hline$A^{T}=0.15$ & Level parameter, tradables production \\
\hline$A^{N T}=0.15$ & Level parameter, non-tradables production \\
\hline$A^{S}=0.725$ & Level parameter, transactions technology \\
\hline$a=-1.164$ & Net foreign assets \\
\hline$r=1 \%$ & Quarterly real interest rate \\
\hline$\beta=0.99$ & Discount factor \\
\hline$\delta=0.025$ & Depreciation rate \\
\hline$T=0.219$ & Land Endowment \\
\hline \multicolumn{2}{|c|}{ Parameters, Model with Distribution } \\
\hline \multicolumn{2}{|c|}{} \\
\hline$\phi=1$ & Distribution coefficient \\
\hline$T=0.34$ & Land Endowment \\
\hline$a=-1.225$ & Net foreign assets \\
\hline
\end{tabular}

While we view our baseline parametrization as a plausible benchmark, there is substantial uncertainty about individual parameter values. For this reason we ran numerous experiments to test the sensitivity of the model. While we only report a subset of this information to conserve on space, in all of our results, the model with distribution did remarkably better than the basic model in terms of its implications for the behavior of the $R E R$, while producing equally plausible results for the other variables.

Since our goal is to improve the model's implications for the magnitude of changes in the $R E R$ we will confine ourselves to two simple experiments: a permanent and a temporary stabilization. It is clear that reality falls somewhat 
between these two extreme examples. Agents do not know whether the stabilization will continue, and this uncertainty may be important in explaining certain features, such as the gradual rise of the $R E R$ after the onset of stabilization (see Mendoza and Uribe (1999)).

\section{A Permanent Stabilization}

In period 0 the economy is in the no-stabilization steady state where the quarterly rate of devaluation, $\varepsilon$, is $95 \%$. In period 1 there is an unanticipated stabilization that permanently reduces $\varepsilon$ to zero. Since there are no adjustment costs, the economy reaches a new steady state in period 2. In the experiments reported, we rebate the seignorage revenues to the private sector.

Table 12 describes the response of the different variables to a permanent stabilization in our benchmark model. Table 13 describes the analogue results for the model with distribution.

The economic mechanisms at work in these tables are well-know and thus can be summarized briefly. The permanent decline in inflation reduces the transactions costs associated with consumption and investment purchases and leads to a re-monetization of the economy. The reduction in the effective price of investment generates an investment boom. This is in large part financed by foreign borrowing, creating a current account deficit. The wealth effect caused by the inflation reduction leads to an expansion in consumption. ${ }^{22}$ Since non-tradable consumption has to be produced locally, in the first period of the reform capital

\footnotetext{
${ }^{22}$ When the seignorage revenue is not rebated the wealth effect associated with reducing inflation is larger, making the movements in the RER slightly larger. When seignorage revenues are not rebated the RER appreciates by $11.4 \%$ in the experiment described in Table 10 and $27.4 \%$ in the experiment in Table 11 . For an evaluation of the impact of rebating seignorage see Mendoza and Uribe (1999). In their experiments, which involve the Mexico 1987-1994 temporary stabilization, rebating the seignorage revenue reduces the rise in the relative price of non-tradables from $5 \%$ to $17 \%$.
} 
and labor are reallocated toward the non-tradable sector, leading to a recession in tradables production. In the new steady state the capital stock increase allows the production of both sectors to be higher than in the pre-stabilization steady state. Since non-tradables production requires land, the land price rises.

\begin{tabular}{|l|l|l|l|}
\hline \multicolumn{4}{|c|}{ Table 12 } \\
\hline \multicolumn{4}{|c|}{ Benchmark Model } \\
\hline \multicolumn{4}{|c|}{ Permanent Stabilization } \\
\hline Variables & $t=0$ & $t=1$ & $t=2$ \\
\hline Devaluation rate $(\varepsilon)$ & 0.95 & 0.00 & 0.00 \\
\hline Output, Tradables Sector $\left(Y_{t}^{T}\right)$ & 0.30 & 0.289 & 0.377 \\
\hline Output Non-Tradables Sector $\left(Y_{t}^{N T}\right)$ & 0.131 & 0.141 & 0.137 \\
\hline Employment Tradable Sector $\left(N_{t}^{T}\right)$ & 0.654 & 0.617 & 0.666 \\
\hline Capital Stock $\left(K_{t}\right)$ & 5 & 7.22 & 7.22 \\
\hline Capital Stock, Tradables Sector $\left(K_{t}^{T}\right)$ & 4.35 & 4.25 & 6.33 \\
\hline Consumption, Tradable Good $\left(C_{t}^{T}\right)$ & 0.131 & 0.159 & 0.163 \\
\hline Consumption, Non-Tradable Good $\left(C_{t}^{N T}\right)$ & 0.131 & 0.141 & 0.137 \\
\hline Net Foreign Assets $\left(a_{t-1}\right)$ & -1.16 & -3.39 & -3.39 \\
\hline Relative Price of Non-Tradables $\left(p_{t}\right)$ & 1 & 1.129 & 1.187 \\
\hline Real Balances $\left(m_{t}\right)$ & 0.062 & 1.314 & 0.249 \\
\hline Rental Price of Capital $\left(q_{t}^{K}\right)$ & 0.0407 & 0.0401 & 0.0352 \\
\hline Rental Price of Land $\left(q_{t}^{L}\right)$ & 0.179 & 0.254 & 0.244 \\
\hline Real Wage Rate $\left(w_{t}\right)$ & 0.188 & 0.192 & 0.232 \\
\hline Trade Balance $\left(T B_{t}\right)$ & 0.0116 & -2.215 & 0.034 \\
\hline Real Exchange Rate $\left(R E R_{t}\right)$ & 1 & 0.941 & 0.918 \\
\hline Percentage Change in $R E R(\%)$ & 0 & -6.02 & -8.51 \\
\hline Real Wage Deflated by CPI $\left.\left(w_{t} /\left[\left(1+\phi p_{t}\right)^{\gamma} p_{t}^{1-\gamma}\right]\right]\right)$ & 0.188 & 0.181 & 0.213 \\
\hline
\end{tabular}




\begin{tabular}{|l|l|l|l|}
\hline \multicolumn{4}{|c|}{ Table 13 } \\
\hline \multicolumn{3}{|c|}{ Model with Distribution } \\
\hline \multicolumn{3}{|c|}{ Permanent Stabilization } & \multicolumn{3}{l|}{} \\
\hline Variables & $t=0$ & $t=1$ & $t=2$ \\
\hline Devaluation rate $(\varepsilon)$ & 0.95 & 0.00 & 0.00 \\
\hline Output, Tradables Sector $\left(Y_{t}^{T}\right)$ & 0.213 & 0.187 & 0.250 \\
\hline Output Non-Tradables Sector $\left(Y_{t}^{N T}\right)$ & 0.203 & 0.226 & 0.223 \\
\hline Employment Tradable Sector $\left(N_{t}^{T}\right)$ & 0.463 & 0.386 & 0.442 \\
\hline Capital Stock $\left(K_{t}\right)$ & 4.10 & 5.7 & 5.7 \\
\hline Capital Stock, Tradables Sector $\left(K_{t}^{T}\right)$ & 3.083 & 2.822 & 4.197 \\
\hline Consumption, Tradable Good $\left(C_{t}^{T}\right)$ & 0.068 & 0.08 & 0.0803 \\
\hline Consumption, Non-Tradable Good $\left(C_{t}^{N T}\right)$ & 0.135 & 0.146 & 0.143 \\
\hline Net Foreign Assets $\left(a_{t-1}\right)$ & -1.225 & -2.733 & -2.733 \\
\hline Relative Price of Non-Tradables $\left(p_{t}\right)$ & 1 & 1.211 & 1.281 \\
\hline Real Balances $\left(m_{t}\right)$ & 0.0596 & 1.016 & 0.251 \\
\hline Rental Price of Capital $\left(q_{t}^{K}\right)$ & 0.0407 & 0.039 & 0.0352 \\
\hline Renital Price of Land $\left(q_{t}^{L}\right)$ & 0.179 & 0.30 & 0.305 \\
\hline Real Wage Rate $\left(w_{t}\right)$ & 0.188 & 0.199 & 0.232 \\
\hline Trade Balance $\left(T B_{t}\right)$ & 0.011 & -1.6 & 0.027 \\
\hline Real Exchange Rate $\left(R E R_{t}\right)$ & 1 & 0.864 & 0.827 \\
\hline Percentage Change in $R E R(\%)$ & 0 & -14.56 & -18.97 \\
\hline Real Wage Deflated by CPI $\left(w_{t} /\left[\left(1+\phi p_{t}\right)^{\gamma} p_{t}^{1-\gamma}\right]\right)$ & 0.133 & 0.122 & 0.136 \\
\hline Distribution Margin $(\phi p /(1+\phi p))$ & 0.5 & 0.548 & 0.562 \\
\hline $\begin{array}{l}\text { Price of Non-Tradables Relative } \\
\text { to Retail Price of Tradables }(p /(1+\phi p))\end{array}$ & 0.5 & 0.548 & 0.562 \\
\hline Percentage Change, Wholesale Price Index $\left(1+\phi^{w} p_{t}\right)(\%)$ & 0 & 6.78 & 8.96 \\
\hline
\end{tabular}

There are four areas in which the model with distribution performs better than the basic model. First, the model with distribution produces a much larger $R E R$ appreciation-the RER declines by $8.5 \%$ in the basic model and by $19 \%$ in the model with distribution. To show that this is a generic feature of our environment we report in Table 14 the $R E R$ movements for various combinations of the elasticity of substitution between land and value added in non-tradables production $(\rho)$, and the fraction of the retail price accounted for by distribution. ${ }^{23}$

\footnotetext{
${ }^{23}$ In all these experiments $A^{S}$ was adjusted so that seignorage was $7 \%$ of GDP in the pre-
} 
The last row of this table provides an upper bound on the $R E R$ appreciation in the context of our experiment. This pertains to the case where the production of non-tradables is constant since it is Leontief in land and the stock of land is fixed. In the model without distribution, it is virtually impossible to generate a $R E R$ appreciation of more than $12 \%$. In contrast, in the model with distribution there are several plausible combinations of parameters that produce realistic movements in the $R E R$.

\begin{tabular}{|c|c|c|c|c|c|}
\hline \multicolumn{6}{|c|}{ Table 14 } \\
\hline \multicolumn{5}{|c|}{ Percentage Change in RER (\%) } \\
\hline & & \multicolumn{5}{|c|}{ Distribution Margin } \\
\hline & & 0 & 25 & 50 & 75 \\
\hline & -1 & -6.7 & -9.3 & -11.5 & -13.5 \\
\hline$\rho$ & $-1 / 3$ & -8.5 & -13.8 & -19.0 & -22.9 \\
\hline & $-1 / 5$ & -9.6 & -17.5 & -26.9 & -34.2 \\
\hline & $-\infty$ & -11.7 & -34.6 & -94.0 & -100.0 \\
\hline
\end{tabular}

Second, the model with distribution has more realistic implications for the sources of $R E R$ fluctuations. In the basic model all of the movement in the $R E R$ is caused by changes in the relative price of non-tradables. In contrast, Section 2 provides evidence that in the Argentine data, only $1 \%$ of the $25 \% R E R$ appreciation is accounted for by changes in the relative price of non-tradables. In the distribution model the $R E R$ falls by $19 \%$, with $13 \%$ of this change explained by chances in the retail price of tradables and only $6 \%$ explained by the changes in the price of non-tradables.

Third, the model is consistent with the differences between the CPI-based $R E R$ and the PPI-based $R E R$ (see panel 1 and 2 of Figure 1). While the CPIbased $R E R$ appreciated by $25.3 \%$ in the first two years of the stabilization plan, stabilization steady state. The pre-stabilization level of $a$ was also adjusted to be consistent with a trade balance of $2.7 \%$. 
the WPI-based RER appreciated only by $2.7 \%$. By April 1996 the total depreciation relative to April 1991 of the CPI-based exchange rate was $28 \%$, compared with only $10 \%$ for the PPI-based $R E R$. In the model the $R E R$ appreciation of the CPI based index is also much more pronounced than the movement in the WPI-based $R E R$ (19\% versus $9 \%) .{ }^{24}$

Fourth, an inherent feature of the basic model is that large $R E R$ appreciations come at the expense of implausible declines in the tradable-non-tradable consumption mix $\left(C^{N T} / C^{T}\right)$. Large appreciations also tend to generate a counterfactual fall in the consumption of non-tradables. Both of these problems are avoided in the model with distribution because the relative price of non-tradables in terms of the retail price of tradables $\left(p_{t} /\left(1+\phi p_{t}\right)\right)$ increases by less that $p_{t}$. Since consuming tradable goods requires the use of non-tradable distribution services, when the price of non-tradables rises there is less scope for substituting toward tradable consumption.

Can we replicate the results of the model with distribution simply by reducing $\gamma$ in the basic model? The answer is no. In our calibration of the distribution model, half of the price of tradable goods is accounted for by distribution services. Since tradable consumption represents half of total consumption expenditure, this means that the non-tradable component of consumption is $75 \%$ ( $50 \%$ devoted to purchasing non-traded goods and $25 \%$ to distribution services associated with the consumption of traded goods). Thus we set $\gamma$ to 0.25 . This re-parameterization does succeed in generating a higher $R E R$ appreciation (15\%). However, this comes at cost of changes in tradable-non-tradable consumption mix that are even less realistic than in the model with $\gamma=0.5$.

\footnotetext{
${ }^{24}$ We computed the wholesale price index for Argentina as $\left(1+\phi^{w} p_{t}\right)$. Note that the only nontradable components in this index are the wholesale distribution costs. Since Table 7 suggests that value added is similar in retail and wholesale, we set $\phi^{w}=0.5$. This choice is likely to bias the results against us since it probably includes too much distribution costs in the WPI, making it more similar to the CPI than in the data.
} 
If we abstract from differences in the CPI weights in the two countries, we can think of movements in the $R E R$ as involving two components. (see equation (2.1) with $\left.\gamma_{U S}=\gamma_{A r}\right) \cdot{ }^{25}$ The first component, which we denote by $R E R^{T}$, is the change in the relative retail price of tradable goods in the two countries. The second component, which we denote by $R E R^{N T}$, is the relative, relative price of non-traded goods in terms of the producer price of tradables. In our model these components can be written as:

$$
\begin{aligned}
R E R^{T} & =\frac{S_{t} P^{T *}}{P^{T}}=\frac{1+\phi p_{t}^{*}}{1+\phi p_{t}} \frac{S_{t} \bar{P}_{t}^{T *}}{\bar{P}_{t}^{T}}=\frac{1+\phi p_{t}^{*}}{1+\phi p_{t}} \\
R E R^{N T} & =\frac{P_{t}^{N T *} / P^{T *}}{P_{t}^{N T} / P_{t}^{T}}=\frac{p_{t}^{*} /\left(1+\phi p_{t}^{*}\right)}{p_{t} /\left(1+\phi p_{t}\right)}
\end{aligned}
$$

Note that the movements in $R E R^{T}$ and $R E R^{N T}$ have a single source, which is changes in the relative price of non-tradables with respect to producer prices $\left(p_{t}\right)$. This makes the movements in $R E R^{T}$ generated by the model closely related to movements in $R E R^{N T}$. The last two panels of Figure 1 depict the logarithm of $R E R^{T}$ and $R E R^{N T}$. Both $R E R^{T}$ and $R E R^{N T}$ were normalized to be one in April 1991. These series share a similar trend. The variable $R E R^{T}$ tracks closely the evolution of $R E R$. In contrast movements in $R E R^{N T}$ are much smaller in magnitude and display some high frequency movements that are not captured by our simple model. ${ }^{26}$ These movements could reflect, for instance, nominal rigidities and pricing to market which invalidate the equation $S_{t} \bar{P}_{t}^{T *}=\bar{P}_{t}^{T}$, and/or the presence of distribution costs that are not related to the price of non-tradables. ${ }^{27}$

\footnotetext{
${ }^{25}$ We thank Charles Engel for suggesting these calculations to us.

${ }^{26}$ The raw correlation between $R E R^{T}$ and $R E R^{N T}$ is 0.84 , which reflects the fact that the trend component of the two series is similar. In contrast the correlation between the cyclical component of both series (extracted with the Hodrick-Prescott filter) is -0.58 .

${ }^{27}$ Engel (2000) argues that the correlation between distribution costs and the relative price of non-tradables has to be low in order to explain movements in the Mexico-US RER.
} 


\subsection{On the Accuracy of Linearization Methods}

Since linearizations are often used to study the effects of stabilization in models similar to the ones we study, it is useful to evaluate their performance against the results of our simple shooting method. Table 15 shows the movements in the $R E R$ produced by both numerical methods.

\begin{tabular}{|l|l|l|}
\hline \multicolumn{3}{|c|}{ Table 15 } \\
\hline \multicolumn{3}{|c|}{ Effect of Permanent Stabilization on RER (\%) } \\
\hline & Linearized & Non-Linearized \\
\hline Basic Model & $-5.0 \%$ & $-8.5 \%$ \\
\hline Model with Distribution & $-10.2 \%$ & $-19.0 \%$ \\
\hline
\end{tabular}

Linearization methods are unusually inaccurate in terms of their implications for the behavior of the $R E R$. This is not surprising for two reasons. First we are studying a large shock that takes the economy far from its initial steady state. Second, this shock has permanent effects and the economy never returns to the initial steady state.

\subsection{Investment Irreversibility and Capital Immobility}

In the previous model, employment in tradables falls in the aftermath of a stabilization. Since in the basic model capital is mobile across sectors, the capital from tradables is reallocated to the non-tradable sector, thus dampening movements in the real exchange rate. Making capital immobile and investment irreversible shuts down this channel of reallocation and magnifies the movements in the real exchange rate. ${ }^{28}$ We now consider a model with both of these features. This requires modifying the model by eliminating equation (3.4) and replacing equation (3.5) with:

$$
K_{t}^{T}=I_{t}^{T}+(1-\delta) K_{t-1}^{T},
$$

\footnotetext{
${ }^{28} \mathrm{An}$ alternative pursued in the literature that has some of the same effects is to introduce adjustment costs to investment in both tradables and non-tradables.
} 


$$
\begin{aligned}
K_{t}^{N T} & =I_{t}^{N T}+(1-\delta) K_{t-1}^{N T} \\
I_{t}^{T} & \geq 0, I_{t}^{N T} \geq 0
\end{aligned}
$$

We also need to define total investment, which enters the household's budget constraint, (3.6), and equilibrium condition (3.14), as:

$$
I_{t}=I_{t}^{T}+I_{t}^{N T}
$$

In the experiment described in Table 16 investment irreversibilities are not binding once sectoral capital immobility is imposed. Sectoral immobility is binding in period 2; the economy would like to reallocate capital from the tradable to the non-tradable sector in this period. Table 16 shows that sectoral immobility substantially enhances the effect of stabilization on the $R E R$ in the period when the shock takes place. In the model with distribution, sectoral capital immobility strengthens the movement in the $R E R$ from $-14.6 \%$ to $-23.9 \%$.

\begin{tabular}{|l|l|l|l|l|}
\hline \multicolumn{6}{|c|}{ Table 16 } \\
\hline & \multicolumn{2}{|c|}{$\begin{array}{c}\text { Without Sectoral } \\
\text { Immobility }\end{array}$} & \multicolumn{2}{c|}{$\begin{array}{c}\text { With Sectoral } \\
\text { Immobility }\end{array}$} \\
\hline & $\mathrm{t}=1$ & $\mathrm{t}=2$ & $\mathrm{t}=1$ & $\mathrm{t}=2$ \\
\hline & -6.0 & -8.5 & -7.6 & -8.5 \\
\hline Basic Model & -14.6 & -19.0 & -23.9 & -19.0 \\
\hline Model with Distribution & & &
\end{tabular}

\subsection{Incorporating a Construction Sector}

According to the 1992 US Input-Output matrix, roughly half of investment emanates from the construction sector. In the 1997 Input-Output table for Argentina, construction accounts for $63 \%$ of investment purchases. Thus, construction, which is a non-tradable good, is an important component of investment. In this subsection we introduce a construction sector into our model. This will provide a natural source of adjustment costs and will lead the economy to converge slowly toward 
the new steady state, We assume that to install one unit of capital requires one unit of the tradable good and $\phi^{I}$ units of construction. The construction sector combines labor $\left(N_{t}^{C}\right)$ and capital $\left(K_{t}^{C}\right)$ according to a Cobb-Douglas production function. The production structure of the model is characterized by the following equations, together with equations (3.11), (6.1), (6.2), and (6.3).

$$
\begin{aligned}
\phi^{C} C_{t}^{T}+C_{t}^{N T} & =\left\{v\left[A^{N T}\left(K_{t}^{N T}\right)^{1-\eta}\left(1-N_{t}^{T}-N_{t}^{C}\right)^{\eta}\right]^{(1+\rho) / \rho}+(1-v) T^{(1+\rho) / \rho}\right\}^{\rho /(1+\rho)} \\
K_{t}^{C} & =I_{t}^{C}+(1-\delta) K_{t-1}^{C} \\
I_{t}^{C} & \geq 0 \\
\phi^{I} I_{t} & =A^{C}\left(K_{t}^{C}\right)^{1-\mu}\left(N_{t}^{C}\right)^{\mu} \\
I_{t} & =I_{t}^{T}+I_{t}^{N T}+I_{t}^{C}
\end{aligned}
$$

There is substantial uncertainty about the share of labor in the Argentine construction sector. "Mixed income" (which is the analogue of proprietors income in the US) represents roughly $30 \%$ of total value added in this sector. Since in the US the construction labor share is $78 \%$, we suspect that most "mixed income" in construction is in fact labor income. Thus, we used a high value for the labor share $(\mu=66 \%)$ consistent with this hypothesis.

Since our model abstracts from residential investment we estimate the share of non-residential investment accounted for by construction. We adopted a value of $\phi^{I}$ such that $25 \%$ of investment is produced by the construction sector. ${ }^{29}$

We maintain the assumptions that investment is irreversible and immobile across sectors. Without these assumptions capital would be reallocated in the

\footnotetext{
${ }^{29} \mathrm{This}$ is a rough estimate based on the following calculations. We assumed that construction is $100 \%$ of residential investment. Based on data for Mexico (we could not find comparable information for Argentina) we assumed that residential investment is $50 \%$ of total investment. Together with the fact that construction represents $63 \%$ of investment in Argentina this implies that the share of non-residential investment accounted for by construction is roughly $25 \%$.
} 
period when the stabilization takes place, from the tradables and non-tradables sector to construction. Table 17 , which summarizes the $R E R$ implications of different models, shows that this would significantly reduce the change in the $R E R$ produced by the model in the period where the shock takes place: from $-25.5 \%$ to $-17.3 \%$.

Figure 2 depicts the effect of a permanent stabilization. All the variables are expressed as percentage deviations from the initial steady state. As in our prior experiments, the decline in the rate of inflation reduces the costs of investment and creates an investment boom. Since construction is required for investment, both labor and capital are re-allocated toward construction in the initial periods after the shock. This leads to a sharper decline in the output of the tradable sector than in a model without construction. The irreversibility constraint on capital is binding in the tradable sector during the first 6 periods since during this time, the economy would like to reallocate capital to the construction sector to invest at a faster rate.

This version of the model captures the important boom-recession cycle in construction that tends to take place during exchange-rate-based stabilization episodes. Table 17 shows that the incorporation of construction leads to a higher $R E R$ appreciation during the transition to the steady state, but to a lower steady state effect than the model with distribution and no construction: This reduction in the magnitude of the $R E R$ 's steady state response is driven by the fact that the introduction of the construction sector increase the cost of investing and reduce the wealth effect associated with the stabilization. 


\begin{tabular}{|l|l|l|l|l|}
\hline \multicolumn{5}{|c|}{ Table 17 } \\
\hline \multicolumn{5}{|c|}{ Effect of Permanent Stabilization on $R E R(\%)$} \\
\hline Time Period & 1 & 2 & 3 & $\infty$ \\
\hline Basic Model & -6.0 & -8.5 & -8.5 & -8.5 \\
\hline Model with Distribution & -14.6 & -19.0 & -19.0 & -19.0 \\
\hline Basic Model with Construction & -7.8 & -7.8 & -7.8 & -7.8 \\
\hline Model with Distribution and Construction & -17.3 & -17.3 & -17.3 & -17.3 \\
\hline $\begin{array}{l}\text { Model with Distribution, Construction } \\
\text { Sectoral Immobility of Capital } \\
\text { and Investment Irreversibility }\end{array}$ & -25.5 & -24.9 & -22.6 & -17.3 \\
\hline
\end{tabular}

\section{A Temporary Stabilization}

The fact that most stabilizations fail has led economists to study the effects of stabilizations that are temporary (see e.g. Calvo and Végh (1993)). In this section we compare the implications of the model, with and without a distribution sector for a stabilization that is known to last for only $T=10$ periods. We assume that investment is irreversible. Without this friction these models produce degenerate results. In period $T$, as inflation rises to its previous level the effective price of investing increases dramatically. Thus agents will attempt to invest sharply in period $T-1$ and then disinvest in period $T$. In our experiment this constraint binds for 38 periods after the end the stabilization.

Figure 3 shows the dynamics of the model with distribution. The dynamics of the basic model are similar, but the movements in the $R E R$ are more attenuated. Table 18 compares the behavior of the $R E R$ in the two models.

\begin{tabular}{|l|l|l|l|l|l|l|}
\hline \multicolumn{7}{|c|}{ Table 18 } \\
\hline \multicolumn{7}{|c|}{ Effect of Temporary Stabilization on $\overline{R E R}(\%)$} \\
\hline Time Period & 1 & 2 & 10 & 11 & 12 & $\infty$ \\
\hline Devaluation rate $(\varepsilon)$ & 0 & 0 & 0 & 95 & 95 & 95 \\
\hline Basic Model & -2.1 & -4.9 & -4.9 & -8.2 & -8.0 & -0.8 \\
\hline Model with Distribution & -4.7 & -10.3 & -10.3 & -16.4 & -16.0 & -1.8 \\
\hline
\end{tabular}


At time 1, the first period of the exchange-rate-based stabilization, consumption of both tradables and non-tradables rises for two reasons. First there is the wealth effect associated with the stabilization. Second, the effective price of consumption is low during the stabilization period but will become high again after period 10. This leads to intertemporal substitution in consumption which contributes to the boom. The economy reallocates labor towards the non-tradable sector in period 1, in order to increase consumption of non-tradables and to provide the distribution services needed to consume more tradables. As a result, the production of tradables falls at time 1.

The decline in the effective price associated with the reduction in inflation leads to an investment boom which is financed mostly by borrowing from abroad, leading to large current account deficits. The investment response is particularly acute in period 10 when the change in its effective price is imminent. This large investment flow raises the capital stock in the tradable sector in period 11. Since tradables are capital intensive, this leads to a rise in the relative price of non-tradables and to an appreciation of the $R E R$. In the following periods the irreversibility constraint on investment is binding and the capital stock falls at the rate of depreciation, leading to a smooth decline in the $R E R$.

\section{Conclusion}

Economists often mention distribution costs as one of the reasons why purchasing power parity fails. Distribution services are intensive in labor and land and thus introduce a natural wedge between the price of the same good in different countries. However, distributing costs are often thought to be too small to be an important determinant of the $R E R$. In this paper we gather evidence that suggests that the fraction of the retail price accounted for by distribution costs is large: roughly $50 \%$ for the average consumption good and as high as $80 \%$ for 
some goods. This evidence lead us to study the $R E R$ implications of a model that incorporates a simple distribution sector. Since there is a large literature on the behavior of the RER during exchange-rate-based stabilizations, these episodes provide a natural road test for our theory. We thus calibrate our model to the Argentine 1991 Convertibility plan and study its implications for the RER. While incorporating a distribution sector in the standard model is technically trivial, this small extension of the standard model improves its performance significantly. The model with distribution can produce large $R E R$ movements without generating a fall in non-tradable consumption or unrealistically pronounced movements in the price of non-tradable goods relative to the retail price of tradables and in distribution margins.

We study several more complex variants of the distribution model. We first consider the effects of investment irreversibilities and sectoral immobility in the stock of capital. This enhances the $R E R$ appreciations that the model is capable of producing in the transition to the steady state. Then, motivated by the fact a substantial part of investment is supplied by the construction sector, we explore the effects of introducing a construction sector whose output is required to install new capital. This produces a smooth adjustment of the economy toward the steady state and a realistic boom-recession cycle in the construction sector.

While we focus on the behavior of the RER during exchange-rate-based stabilizations, the model with distribution may be useful in studying the behavior of the RER in other contexts. One such context is Cordoba and Kehoe's (1999) study of the Spanish capital flow liberalization, which finds that the magnitude of the $R E R$ appreciation is difficult to rationalize on the basis of their model. Another context is Engel's (1999) empirical investigation of the behavior of the US $R E R$. Engel finds that the relative price of non-tradables does not seem to vary enough to explain a significant fraction of the observed $R E R$ variability. A model 
with a distribution sector can easily generate larger fluctuations in the $R E R$ than in the relative price of non-tradables.

We suspect that incorporating a distribution sector may also contribute to the explanation of several outstanding puzzles in international macroeconomics, namely the fact that the cross country correlation of output is higher than that of consumption (see Backus, Kehoe, and Kydland (1995) and Baxter (1995)) and the fact that consumption is too smooth in a small open economy with standard preferences (see Correia, Neves and Rebelo (1995)). Work on the role that distribution may play in these puzzles would greatly benefit from more information on the behavior of distribution margins across different countries and over time. 


\section{References}

[1] Backus, David, Patrick Kehoe, and Finn Kydland, "International Business Cycles: Theory and Evidence". In Frontiers of Business Cycle Research, T. Cooley (ed.) Princeton University Press, 331-356, 1995.

[2] Bailey, Martin "Competition, Regulation and Efficiency in Service Industries," Brookings Papers: Microeconomics, 2: 71-159, 1993.

[3] Baxter, Marianne, (1995) "International Trade and Business Cycles," in Handbook of International Economics, vol. III, (G. Grossman and K. Rogoff, eds), North-Holland.

[4] Betancourt, Roger "An Analysis of the U.S. Distribution System," Working Paper 92-6, Department of Economics, University of Maryland, 1992.

[5] Benninga, Simon and Protopapadakis, Aris "The Equilibrium Pricing of Exchange Rates and Assets When Trade Takes Time," Journal of International Money and Finance, 7: 129-49, 1998.

[6] Betts, Caroline and Timothy Kehoe, "Tradability of Goods and Real Exchange Rate Variability," working paper, University of Minnesota, 1999.

[7] Calvo, Guillermo, and Carlos A. Végh, "Exchange Rate Based Stabilization under Imperfect Credibility," in Helmut Frisch and Andreas Worgotter, Open Economy Macroeconomics, London: MacMillan, 3-28, 1993.

[8] Calvo, Guillermo and Carlos Végh "Inflation Stabilization and BOP Crises in Developing Countries," John Taylor and Michael Woodford (eds.) Handbook of Macroeconomics, North-Holland, 1531-1614, 1999. 
[9] Cordoba, Gonzalo Fernandez and Timothy Kehoe "Capital Flows and Real Exchange Rates Following Spain's Entry into the European Community," mimeo, University of Minnesota, 1999.

[10] Correia, Isabel, Joao Neves, and Sergio Rebelo, "Business Cycles in a Small Open Economy," European Economic Review, 39: 1089-1113, 1995.

[11] Dornbusch, Rudiger "Real Exchange Rates and Macroeconomics: A Selective Survey," Scandinavian Journal of Economics, 91: 401-432, 1989.

[12] Dumas, Bernard "Dynamic Equilibrium and the Real Exchange Rate in a Spatially Separated World," The Review of Financial Studies, 5: 153-180, 1992.

[13] Engel, Charles "Accounting for US Real Exchange Rate Changes," Journal of Political Economy, 107: 507-538, 1999.

[14] Engel, Charles "Optimal Exchange Rate Policy: The Influence of Price Setting and Asset Markets," mimeo, University of Washington, 2000.

[15] Erceg, Chris and Andrew Levin "Structures and the Dynamic Behavior of the Real Exchange Rate," mimeo, Board of Governors of the Federal Reserve System, 1996.

[16] Euromoney, US Retail Structures, July 1997.

[17] Feenstra, Robert "Integration of Trade and Disintegration of Production in the Global Economy," Journal of Economic Perspectives, 12: 31-50, 1998.

[18] Froot, Kenneth and Kenneth Rogoff "Perspectives on PPP and Long-run Real Exchange Rates," in G. Grossman and K. Rogoff (eds.) Handbook of International Economics, vol. III, 1647-1688, 1995. 
[19] Giovannini, Alberto "Exchange Rates and Traded Goods Prices," Journal of International Economics, 24: 45-68, 1988.

[20] Hummels, David "Toward a Geography of Trade Costs," mimeo, University of Chicago, 1999.

[21] Isard, Peter "How Far Can We Push the Law of One Price?," American Economic Review, 67: 942-948, 1977.

[22] Itoh, Motoșhige "Competition in the Japanese Distribution Market and Market Access from Abroad," in Takatoshi Ito and Anne Krueger Deregulation and Interdependence in the Asia-Pacific Region, NBER-East Asia Seminar on Economics, The University of Chicago Press, 2000.

[23] Kiguel, Miguel "Inflation in Argentina: Stop and Go Since the Austral Plan," World Bank, PPR Working Paper 162, 1989.

[24] Mendoza Enrique and Martin Uribe "Devaluation Risk and the Syndrome of Exchange-Rate-Based Stabilizations," N.B.E.R. Working Paper No. 7014, 1999.

[25] Rauch, James "Networks versus Markets in International Trade," N.B.E.R. working paper N.5617, 1996.

[26] Rebelo, Sergio and Carlos Végh "Real Effects of Exchange-Rate-Based Stabilization: An Analysis of Competing Theories," NBER Macroeconomics Annual 1995, 125-174, The MIT Press,1995.

[27] Reinhart, Carmen M., and Carlos A. Végh, (1995) "Nominal Interest Rates, Consumption Booms, and Lack of Credibility: A Quantitative Examination," Journal of Development Economics, 46: 357-378, 1995. 
[28] Rogoff, Kenneth "The Purchasing Power Parity Puzzle," Journal of Economic Literature, 34: 647-68, 1996.

[29] Roldos, Jorge "Supply-Side Effects of Disinflation Programs," IMF Staff Papers 42: 158-183, 1995.

[30] Sanyal, Kalyan K. and Ronald W. Jones "The Theory of Trade in Middle Products," American Economic Review, 72: 16-31, 1982.

[31] Sercu, Piet, Uppal, Taman, and Van Hulle, Cynthia "The Exchange Rate in the Presence of Transactions Costs: Implications for Tests of the Purchasing Power Parity," Journal of Finance, 50: 1309-19, 1995.

[32] Stockman. Alan and Linda Tesar "Tastes and Technology in a Two-Country Model of the Business Cycle: Explaining International Co-Movements," American Economic Review, 85, 1: 168-185, 1995.

[33] Uribe, Martin "Exchange-Rate-Based Inflation Stabilization: The Initial Real Effects of Credible Plans," Journal of Monetary Economics, 39: 197$221,1997$.

[34] Végh, Carlos "Government Spending and Inflationary Finance: A Public Finance Approach," IMF Staff Papers, 36: 657-677, 1989. 


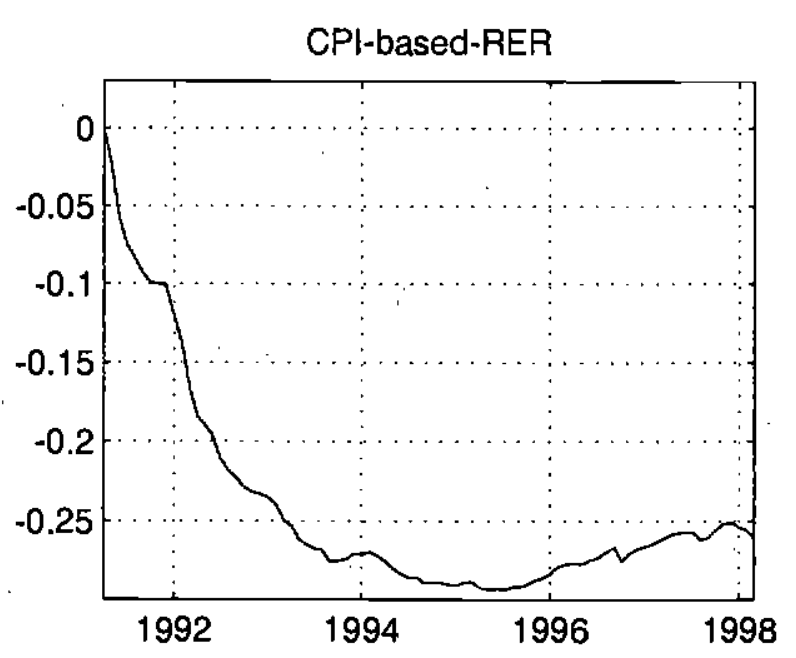

Figure 1

PPI-based-RRER
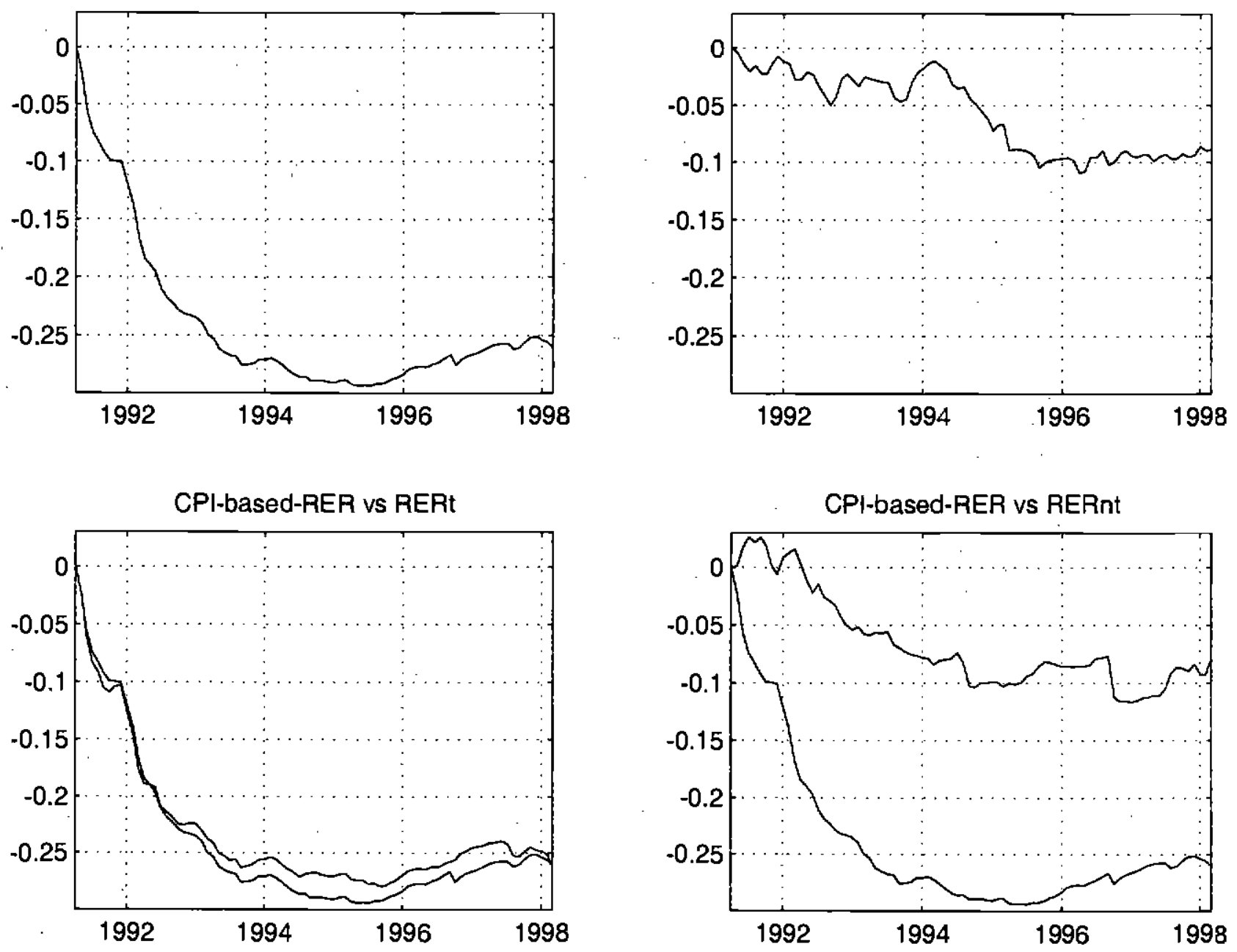
Figure 2: Permanent Stabilization, Model with Construction, Distribution and Irreversibitities
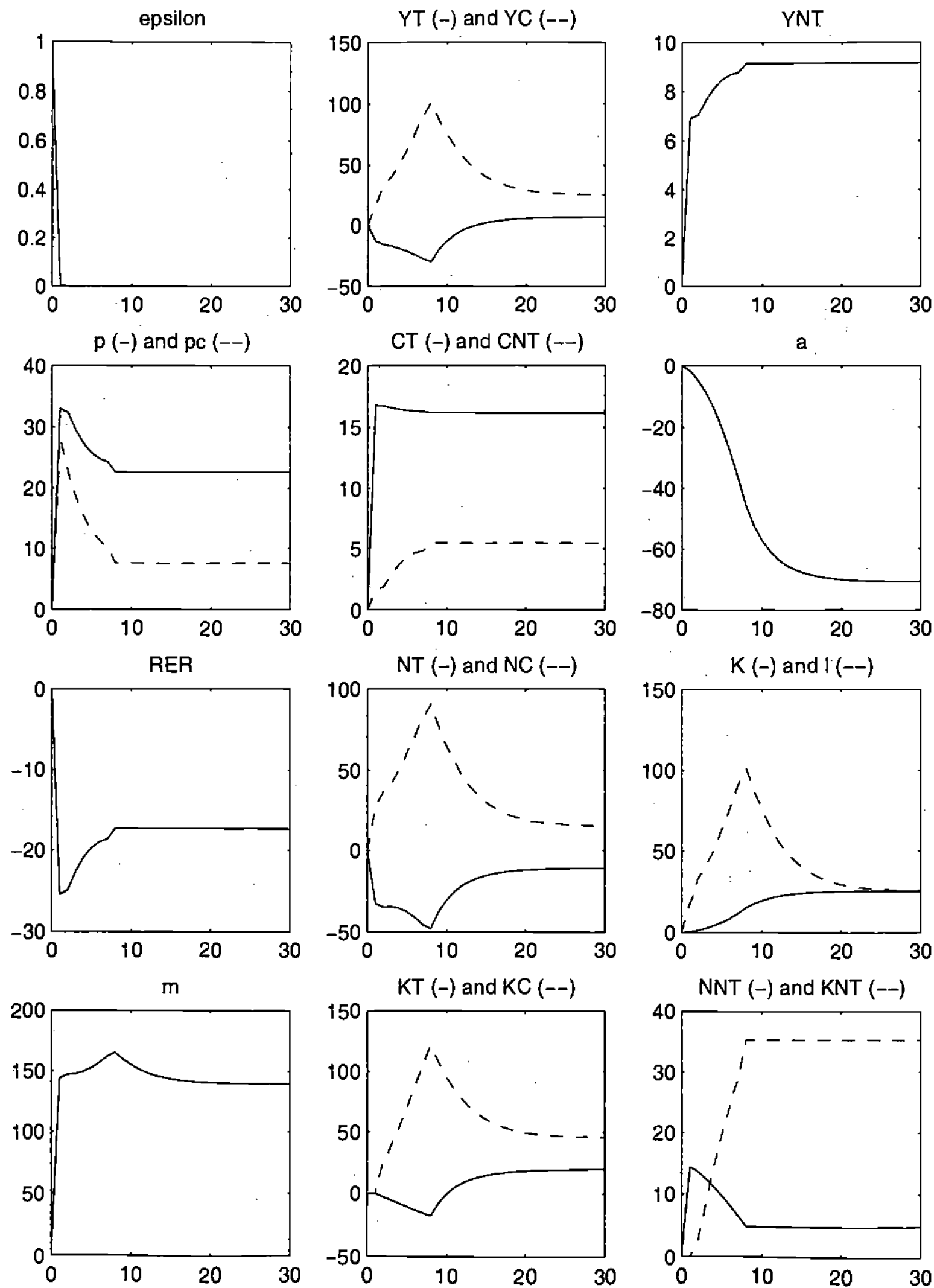
Figure 3: Temporary Stabilization, Model with Distribution and Irreversibilities
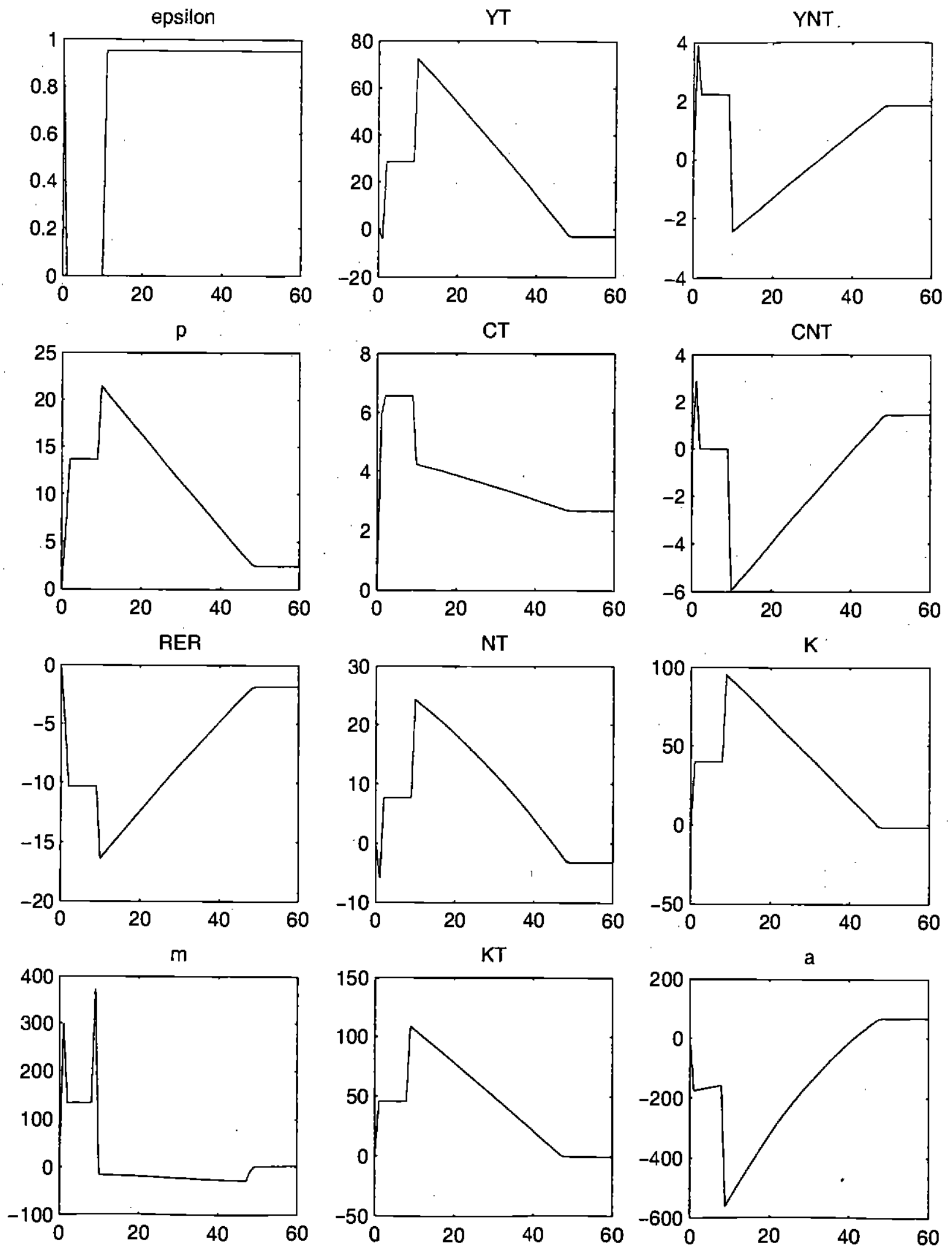
Table 1

Components of Consumer Price Index for Argentina March $1991=1$

\begin{tabular}{|c|c|c|c|c|c|c|c|c|}
\hline & Weight & Mar-92 & \begin{tabular}{|l|} 
Mar-93 \\
\end{tabular} & Mar-94 & Mar-95 & Mar-96 & Mar-97 & Mar-98 \\
\hline Food and Beverages & 40.1 & 1.44 & 1.58 & 1.62 & 1.69 & 1.68 & 1.67 & 1.70 \\
\hline Cereals & 5.3 & 1.36 & 1.54 & 1.70 & 1.76 & 1.93 & 1.90 & 1.86 \\
\hline Meats & 10.0 & 1.60 & 1.65 & 1.61 & 1.63 & 1.62 & 1.59 & 1.80 \\
\hline Fats and oils & 1.0 & 1.14 & 1.30 & 1.61 & 1.72 & 1.74 & 1.67 & 1.81 \\
\hline Dairy & 4.9 & 1.33 & 1.49 & 1.54 & 1.64 & 1.70 & 1.81 & 1.85 \\
\hline Fruits & 2.7 & 1.76 & 1.52 & 1.50 & 1.64 & 1.56 & 1.62 & 1.58 \\
\hline Vegetables & $\overline{3.4}$ & 1.52 & 1.95 & 1.75 & 1.92 & 1.77 & 1.84 & $\overline{1.75}$ \\
\hline Sugar and sweets & 1.5 & 1.03 & 1.12 & 1.22 & 1.25 & 1.21 & 1.24 & 1.22 \\
\hline Teas and coffee & 1.4 & 1.07 & 1.15 & 1.22 & 1.64 & 1.63 & 1.54 & 1.57 \\
\hline Spices & $\overline{0.4}$ & 1.13 & 1.39 & 1.54 & 1.60 & 1.65 & 1.63 & 1.64 \\
\hline Partially prepared Foods & 0.3 & 1.06 & 1.06 & 1.09 & 1.08 & 1.08 & 1.07 & 1.06 \\
\hline Prepared Foods & 1.0 & 1.49 & 1.69 & 1.75 & 1.75 & 1.73 & 1.68 & 1.68 \\
\hline Non-alcoholic beverages & 2.1 & 1.26 & 1.43 & 1.50 & 1.51 & 1.49 & 1.40 & 1.25 \\
\hline Alcoholic Beverages & 1.7 & 1.18 & 1.45 & 1.57 & 1.56 & 1.41 & 1.38 & 1.38 \\
\hline Food away from home & 4.5 & 1.49 & 1.70 & 1.78 & 1.82 & 1.80 & 1.77 & 1.76 \\
\hline Apparel and Upkeep & 9.4 & 1.12 & 1.13 & 1.10 & 1.09 & 1.04 & 1.01 & 0.99 \\
\hline Underclothes & 0.6 & 1.14 & 1.19 & 1.19 & 1.20 & 1.19 & 1.18 & 1.17 \\
\hline Apparal & 5.5 & 1.12 & 1.11 & 1.05 & 1.01 & 0.94 & 0.90 & 0.88 \\
\hline Footwear & 2.2 & 1.10 & 1.12 & 1.08 & 1.10 & 1.06 & 1.03 & 1.01 \\
\hline Other Clothing & 0.5 & 1.11 & $1 . \overline{10}$ & 1.08 & 1.10 & 1.12 & 1.10 & 1.10 \\
\hline Apparel Accessories & 0.4 & 1.08 & 1.11 & 1.10 & 1.09 & .1 .08 & 1.07 & 1.06 \\
\hline Apparel Services & 0.2 & 1.36 & 1.62 & 1.72 & 1.76 & 1.74 & 1.71 & 1.68 \\
\hline Housing & 8.5 & 1.34 & 1.63 & 1.80 & 1.91 & 1.94 & 1.94 & 1.93 \\
\hline Rents, residential & 2.3 & 1.58 & 2.22 & 2.70 & 2.83 & 2.82 & 2.75 & 2.73 \\
\hline Maintenance and repairs & 2.0 & 1.28 & 1.50 & 1.62 & 1.71 & 1.70 & 1.69 & 1.68 \\
\hline Fuel and other utilities & 4.2 & 1.24 & 1.39 & 1.42 & 1.53 & 1.62 & 1.66 & 1.68 \\
\hline Household Furnish. and Oper. & 8.6 & 1.21 & 1.37 & 1.42 & 1.46 & 1.46 & 1.44 & 1.44 \\
\hline Furniture and Bedding & 1.1 & 1.12 & 1.18 & 1.18 & 1.19 & 1.19 & 1.17 & 1.16 \\
\hline Domestic Appliances & 1.2 & 1.00 & 0.91 & 0.88 & 0.83 & 0.83 & 0.81 & 0.79 \\
\hline Textiles and Decoration & 0.9 & 1.10 & 1.08 & 1.06 & 1.06 & 1.06 & 1.04 & 1.03 \\
\hline Housekeeping & 0.4 & 1.10 & 1.14 & 1.12 & 1.11 & 1.12 & 1.10 & 1.09 \\
\hline Housekøeping Supplies & 1.8 & 1.12 & 1.21 & 1.23 & 1.24 & 1.25 & 1.25 & 1.26 \\
\hline Housekeeping Services & 2.9 & 1.41 & 1.77 & 1.90 & 2.01 & 2.00 & 1.99 & 1.99 \\
\hline Iflumination and Hardware & 0.3 & 0.95 & 1.00 & 1.02 & 1.04 & 1.07 & 1.09 & 1.11 \\
\hline Medical Care & 7.2 & 1.31 & 1.56 & 1.75 & 1.86 & 1.89 & 1.89 & 1.90 \\
\hline Medical Care Commodities & 4.4 & 1.06 & 1.24 & 1.44 & 1.55 & 1.60 & 1.61 & 1.62 \\
\hline Medical Care Services & 2.8 & 1.50 & 1.80 & 1.98 & 2.09 & 2.11 & 2.10 & 2.12 \\
\hline Transportation & 11.4 & 1.07 & 1.17 & 1.23 & 1.33 & 1.35 & 1.53 & 1.59 \\
\hline Public transportation & 3.2 & 1.08 & 1.25 & 1.40 & $1 . \overline{67}$ & 1.67 & 1.93 & 2.20 \\
\hline New vehicles (new and used cars) & 1.5 & 1.04 & 1.06 & 1.06 & 1.06 & 1.08 & 1.08 & 1.05 \\
\hline Maintenance and repair of private tranp. & 5.9 & 1.07 & 1.15 & 1.18 & 1.22 & 1.26 & 1.36 & 1.35 \\
\hline Communication & 0.8 & 1.17 & 1.32 & 1.39 & $1 . \overline{42}$ & 1.49 & 2.43 & 2.43 \\
\hline Leisure & 6.2 & 1.34 & 1.43 & 1.59 & 1.71 & 1.71 & 1.75 & 1.76 \\
\hline Entertainment & 1.1 & 1.06 & 1.10 & 1.11 & 1.09 & 1.13 & 1.10 & 1.08 \\
\hline
\end{tabular}




\begin{tabular}{|l|c|c|c|c|c|c|c|c|}
\hline Books, newspapers and magazines & 1.1 & 1.13 & 1.24 & 1.35 & 1.56 & 1.64 & 1.59 & 1.59 \\
\hline Tourism & 1.8 & 1.55 & 1.55 & 1.81 & 1.99 & 1.93 & 2.09 & 2.11 \\
\hline Video and audio equipment & 1.1 & 1.09 & 1.09 & 1.09 & 1.11 & 1.10 & 1.07 & 1.05 \\
\hline Entertainment services & 1.1 & 1.42 & 1.75 & 1.97 & 2.10 & 2.12 & 2.11 & 2.12 \\
\hline Education & $\mathbf{2 . 7}$ & $\mathbf{1 . 2 4}$ & $\mathbf{1 . 5 8}$ & $\mathbf{1 . 7 2}$ & $\mathbf{1 . 8 0}$ & $\mathbf{1 . 8 2}$ & $\mathbf{1 . 8 2}$ & $\mathbf{1 . 8 3}$ \\
\hline Educational Services & 1.8 & 1.28 & 1.67 & $\mathbf{1 . 8 3}$ & 1.90 & 1.92 & 1.93 & 1.93 \\
\hline School Books and Supplies & 0.9 & 1.06 & 1.14 & $\mathbf{1 . 1 7}$ & 1.28 & 1.31 & 1.31 & 1.31 \\
\hline Other Goods and Services & $\mathbf{5 . 9}$ & $\mathbf{1 . 3 2}$ & $\mathbf{1 . 4 0}$ & $\mathbf{1 . 4 4}$ & $\mathbf{1 . 4 6}$ & $\mathbf{1 . 4 6}$ & $\mathbf{1 . 4 7}$ & $\mathbf{1 . 4 6}$ \\
\hline Tobacco & 1.9 & 1.26 & 1.26 & $\mathbf{1 . 2 6}$ & 1.26 & 1.26 & 1.34 & 1.34 \\
\hline Toilet Goods and Personal Care Appliances & 2.4 & 1.12 & $\mathbf{1 . 1 8}$ & $\mathbf{1 . 1 9}$ & 1.20 & 1.24 & 1.23 & 1.23 \\
\hline Personal Care Services & 0.8 & 1.58 & $\mathbf{1 . 8 9}$ & 2.06 & 2.13 & 2.11 & 2.04 & 1.97 \\
\hline Other Services & 0.9 & 1.47 & $\mathbf{1 . 5 4}$ & $\mathbf{1 . 5 5}$ & $\mathbf{1 . 5 7}$ & 1.57 & 1.57 & 1.57 \\
\hline All Items & $\mathbf{1 0 0 . 0}$ & $\mathbf{1 . 3 0}$ & $\mathbf{1 . 4 6}$ & $\mathbf{1 . 5 3}$ & $\mathbf{1 . 6 0}$ & $\mathbf{1 . 6 0}$ & $\mathbf{1 . 6 2}$ & $\mathbf{1 . 6 3}$ \\
\hline
\end{tabular}

Source: Estudio Broda and Indec. 
Table 2

Ratio of US CPI to Argentina CPI by Component

March $1991=1$

\begin{tabular}{|l|c|c|c|c|c|c|c|}
\hline & Mar-92 & Mar-93 & Mar-94 & Mar-95 & Mar-96 & Mar-97 & Mar-98 \\
\hline Cereals & 0.76 & 0.69 & 0.65 & 0.65 & 0.62 & 0.64 & 0.67 \\
\hline Meats & 0.62 & 0.61 & 0.64 & 0.62 & 0.64 & 0.67 & 0.59 \\
\hline Dairy & 0.77 & 0.69 & 0.69 & 0.65 & 0.65 & 0.65 & 0.64 \\
\hline Sugar and Sweets & 1.01 & 0.93 & 0.86 & 0.85 & 0.91 & 0.92 & 0.96 \\
\hline Fats and Oils & 0.86 & 0.76 & 0.62 & 0.60 & 0.61 & 0.64 & 0.59 \\
\hline Non-alcoholic Beverages & 0.80 & 0.70 & 0.67 & 0.77 & 0.76 & 0.81 & 0.93 \\
\hline Food Away From Home & 0.69 & 0.61 & 0.60 & 0.60 & 0.62 & 0.65 & 0.66 \\
\hline Alcoholic Beverages & 0.87 & 0.72 & 0.68 & 0.69 & 0.79 & 0.83 & 0.84 \\
\hline Rents, Residential & 0.65 & 0.47 & 0.40 & 0.39 & 0.40 & 0.42 & 0.44 \\
\hline Fuel and Other Utilities & 0.82 & 0.76 & 0.75 & 0.70 & 0.68 & 0.69 & 0.66 \\
\hline Furniture and Bedding & 0.93 & 0.90 & 0.92 & 0.95 & 0.96 & 0.99 & 1.01 \\
\hline Housekeeping Supplies & 0.90 & 0.83 & 0.84 & 0.85 & 0.88 & 0.89 & 0.90 \\
\hline Footwear & 0.94 & 0.93 & 0.97 & 0.95 & 1.00 & 1.02 & 1.04 \\
\hline New Vehicles (new and used cars) & 0.98 & 0.99 & 1.03 & 1.05 & 1.05 & 1.07 & 1.09 \\
\hline Maintenance, Repair of Transportation & 0.98 & 0.93 & 0.95 & 0.93 & 0.93 & 0.88 & 0.92 \\
\hline Public Transportation & 0.93 & 0.85 & 0.83 & 0.68 & 0.70 & 0.64 & 0.57 \\
\hline Medical Care Commodities & 1.01 & 0.90 & 0.80 & 0.76 & 0.75 & 0.77 & 0.78 \\
\hline Medical Care Services & 0.72 & 0.64 & 0.61 & 0.61 & 0.63 & 0.65 & 0.67 \\
\hline Tobacco & 0.86 & 0.95 & 0.88 & 0.90 & 0.93 & 0.90 & 0.96 \\
\hline Toilet Goods and Personal Care Appl. & 0.93 & 0.89 & 0.89 & 0.90 & 0.88 & 0.89 & 0.91 \\
\hline Personal Care Services & 0.65 & 0.56 & 0.52 & 0.52 & 0.54 & 0.58 & 0.62 \\
\hline School Books and Supplies & 1.00 & 0.97 & 0.98 & 0.94 & 0.97 & 1.01 & 1.07 \\
\hline Educational Services & 0.87 & 0.74 & 0.72 & 0.74 & 0.77 & 0.81 & 0.84 \\
\hline
\end{tabular}

Source: Estudio Broda, Indec, and DRI BASIC Economics. 
Table 6

US Retail and Wholesale Trade, 1992

Margins, Value Added and Labor Compensation

\begin{tabular}{|c|c|c|c|}
\hline & \begin{tabular}{|l|} 
Gross Margin/ \\
Sales (\%) \\
\end{tabular} & $\begin{array}{l}\text { Value Added/ } \\
\text { Sales (\%) } \\
\end{array}$ & \begin{tabular}{|l|} 
Labor Compensation'/1 \\
Value Added (\%) \\
\end{tabular} \\
\hline Retail Trade & 32.2 & 30.4 & 48.9 \\
\hline Durable Goods Stores & 26.8 & 25.6 & 47.9 \\
\hline \begin{tabular}{|l|} 
Non-Durable Goods Stores \\
\end{tabular} & 35.3 & 33.1 & 49.2 \\
\hline $\begin{array}{l}\text { Building Materials, hardware, } \\
\text { garden supplies and mobile home } \\
\text { dealers }\end{array}$ & 31.3 & 29.7 & 52.5 \\
\hline Building materials and supply stores & 29.7 & 28.1 & 53.6 \\
\hline Hardware stores & 36.5 & 34.7 & 52.6 \\
\hline $\begin{array}{l}\text { Lawn and garden stores and mobile } \\
\text { home dealers }\end{array}$ & 35.9 & 34.1 & 46.3 \\
\hline General merchandise stores & 30.6 & 29.2 & 48.5 \\
\hline Food stores & 25.5 & 23.4 & 59.4 \\
\hline Grocery stores & 24.4 & 22.4 & 60.1 \\
\hline Other food stores & 47.2 & 43.0 & 50.8 \\
\hline $\begin{array}{l}\text { Automotive dealers and gasoline } \\
\text { service stations }\end{array}$ & 18.8 & 18.1 & 46.3 \\
\hline Franchised motor vehicle dealers & 16.1 & 15.7 & 50.2 \\
\hline Used motor vehicles & 23.9 & 22.8 & 26.8 \\
\hline Auto and home supply & 38.9 & 36.9 & 55.4 \\
\hline Gasoline service stations & 19.4 & 18.3 & $38: 2$ \\
\hline Other automotive dealers & 22.3 & - & \\
\hline Apparel & 42.7 & 40.7 & 41.6 \\
\hline $\begin{array}{l}\text { Men's and boy's clothing and } \\
\text { furnishing stores }\end{array}$ & 43.8 & 41.8 & 49.4 \\
\hline Women's clothing, specialty stores & 44.0 & 41.9 & 38.7 \\
\hline Other apparel & 40.5 & 38.6 & 42.9 \\
\hline Shoe stores & 44.5 & 42.7 & \\
\hline $\begin{array}{l}\text { Furniture and homefurnishings and } \\
\text { equipment stores }\end{array}$ & 37.9 & 36.2 & 45.0 \\
\hline Furniture and homefurnishings & 43.7 & 41.8 & 42.5 \\
\hline Household appliance stores & 33.3 & 31.9 & 50.4 \\
\hline $\begin{array}{l}\text { Radio,Television, computer and music } \\
\text { stores }\end{array}$ & 30.4 & 29.1 & 49.4 \\
\hline Eating and drinking places & 65.4 & 60.2 & 51.6 \\
\hline Eating places & 65.9 & 60.7 & 52.1 \\
\hline Drinking places & 58.7 & 53.3 & \\
\hline Drug and proprietary stores & 26.9 & 25.7 & 56.7 \\
\hline Liquor stores & 24.1 & 22.5 & 37.5 \\
\hline Nonstore retailers & 52.5 & 50.4 & 32.4 \\
\hline Fuel dealers & 37.3 & 36.2 & 45.1 \\
\hline $\begin{array}{l}\text { Miscellaneous retail stores, except } \\
\text { drugs and liquor }\end{array}$ & 45.5 & 42.9 & 43.9 \\
\hline
\end{tabular}

\footnotetext{
${ }^{1}$ Labor compensation includes payroll and employers cost for fringe benefits.
} 
Table 6 (Continuation)

US Retail and Wholesale Trade, 1992

Margins, Value Added and Labor Compensation

\begin{tabular}{|l|l|l|l|}
\hline Merchant Wholesalers & 20.6 & 19.6 & 47.6 \\
\hline $\begin{array}{l}\text { Durable Goods Stores } \\
\text { and supplies }\end{array}$ & $\mathbf{2 5}$ & $\mathbf{2 3 . 9}$ & $\mathbf{4 8 . 4}$ \\
\hline Furnitures and home furnishings & 35.7 & 33.5 & \\
\hline $\begin{array}{l}\text { Lumber and other construction } \\
\text { materials }\end{array}$ & 23.6 & 22.5 & 46.8 \\
\hline $\begin{array}{l}\text { Professional and commercial } \\
\text { equipment and supplies }\end{array}$ & 30.9 & 29.6 & 50.5 \\
\hline Metals and minerals, except petroleum & 20.4 & 19.1 & 50.5 \\
\hline Electrical goods & 24.6 & 23.8 & 46.4 \\
\hline $\begin{array}{l}\text { Hardware, and plumbing and heating } \\
\text { equipment and supplies }\end{array}$ & 27.7 & 26.5 & 43.4 \\
\hline Machinery, equipment, and supplies & 28 & 56.3 \\
\hline Miscellaneous durable goods & 21.9 & 26.7 & 58.7 \\
\hline Nondurable goods & $\mathbf{1 6 . 3}$ & 20.8 & 42.2 \\
\hline Paper and paper products & 22.4 & $\mathbf{1 5 . 4}$ & $\mathbf{4 6 . 8}$ \\
\hline $\begin{array}{l}\text { Drugs, drug proprietaries and } \\
\text { druggists'sundries }\end{array}$ & 11.2 & 21.6 & 57.6 \\
\hline Apparel, piece goods, and notions & 29.2 & 10.7 & 38.4 \\
\hline Groceries and related products & 14.8 & 26.8 & 37.4 \\
\hline Farm-product raw materials & 9.5 & 13.9 & 54.1 \\
\hline Chemicals and allied products & 24.3 & 8.9 & 36.0 \\
\hline Petroleum and petroleum products & 8.9 & 22.9 & 47.6 \\
\hline $\begin{array}{l}\text { Beer, wine and distilled alcoholic } \\
\text { beverages }\end{array}$ & 23.8 & 8.6 & 41.8 \\
\hline Miscellaneous nondurable goods & 21.2 & 23.2 & 41.0 \\
\hline
\end{tabular}

Source: 1992 Census of Retail Trade and 1992 Census of Wholesale Trade, US Department of Commerce. 